\title{
Risk perception of local stakeholders on natural hazards: implications for theory and practice
}

\author{
Mihai Ciprian Mărgărint ${ }^{1}$, Mihai Niculiță ${ }^{1}$, Giulia Roder $^{2}$, Paolo Tarolli ${ }^{3}$
}

${ }^{1}$ Department of Geography, Geography and Geology Faculty, Alexandru Ioan Cuza University of Iaşi, 700505, Iaşi, Romania

$5{ }^{2}$ Department of Economics and Statistics, University of Udine, 33110 Udine, Italy

${ }^{3}$ Department of Land, Environment, Agriculture and Forestry, University of Padova, 35020, Legnaro, Italy

Correspondence to: Mihai Niculiță (mihai.niculita@uaic.ro)

\begin{abstract}
In Romania, local stakeholders' knowledge plays a decisional role in emergencies, supporting rescue officers in natural hazard events, coordinating and assisting, both physically and psychologically, the affected populations. However, despite in Iași Metropolitan area (NE of Romania), the occurrence and severity of natural hazards are increasing there is a lack of knowledge of local stakeholders to address the population toward safety actions. For this reason, 118 local stakeholders were interviewed to determine their risk awareness and preparedness capacities over a set of natural hazards to understand where the lack of knowledge, action, and trust are exacerbated the most. Results reveal substantial distinctions among stakeholders and the different threats based on their cognitive and behavioral roles in the communities. The role of

15 responsibility and trust has been seen as important driving factors shaping their perception and preparedness. Preparedness levels were low, and, not for all, learning and preparatory actions are needed to withstand the negative occurrences of natural hazards. As their role is to refer with direct interventions in affected areas managing communication initiatives with the entire population of the community, there is the need to create stakeholders' networks, empowering local actors that could serve as a bridge between authorities' decisions and local people in order to make effective risk management plans and secure more lives and economies.
\end{abstract}

\section{Introduction}

Increasing the level of preparedness of communities is an essential part of risk management, a complex process that challenges scientists and involves communities, authorities, but also some key stakeholders. Decisions and actions, included the speed of those, have an important role in reducing the vulnerability of communities for improving societal resilience. From global to local, communities are affected every year by disasters. Compared to the 1980-1999 period, the last 20 years are marked by an increase in the number of climate-related disasters with a significantly higher number of people affected and economic losses compared to other types of disasters (UNDRR, 2020, van Westen et al., 2020; excluded epidemiological disasters). Recent studies forecast an increase in climate hazard impacts in the future as a direct consequence of global warming (Dottori et al., 2018; Forzieri et al., 2018; Vousdoukas et al., 2018). Especially in Central and Eastern Europe, there is evidence of an increase in heat extremes, a decrease in summer precipitation, and an increased risk of river floods due to climate changes in 
the last two decades (Anders 2014; IPCC 2013, 2018). These events are able to threaten the wellbeing of communities, especially in Romania, since its population demonstrated to have a low copying capacity of natural hazards induced risks (Dunford et al. 2015; Vanneuville et al. 2017).

In many countries, besides the national government agencies which coordinate emergencies management (Strand et al. 2010) and have much more structural and financial resources, local stakeholders are often involved in disaster planning and risk reduction because of their knowledge of the community, norms, and habits and for their capacity to assist and control people during crises (Meltzer et al. 2018; ERCC, 2019; Scheuer and Haase, 2012; Horton et al. 2011). Local stakeholders are defined as individuals or groups (generally place-based) who demonstrated capacities to coordinate and cooperate before, during, and after emergencies (Hommels and Cleophas, 2013), as widely documented during the recent pandemic crisis (Alon, 2020;

40 WHO, 2020). They are among the best communicators in their settlements (Slovic, 1993; Reed, 2008; Straja et al., 2008), stimulating proactive two-way communication and even run negotiations, being able to influence (positively) the community and acting as a bridge between national authorities' decisions and actions. For certain types of hazards, such as floods, there is already a separation of stakeholders' responsibilities: decisions regarding local flood defense improvements are devolved to local decision-makers, whereas decisions about river training are taken at national and international levels (Merz et al., 2010).

45 A similar situation is encountered in the case of heavy snow, in which case a first assessment and intervention fall under the responsibility of local authorities.

Local stakeholders in Romania play an effective and decisional role in emergencies (Mărgărint and Niculiţă, 2014; Meltzer et al., 2018), helping rescue officers in the onset of natural hazard events, and are able to coordinate and assist, both physically and psychologically, affected populations. People seemed to trust those key agents rather than county or governmental

50 stakeholders (Beshi and Kaur, 2019). At the national level, in Romania, the management of the emergency is coordinated by General Inspectorate for Emergency Situations (IGSU) and at ATU3 (Administrative Territorial Unit) level by the Local Committee for Emerging Situations. According to the specific legislation (NSO - National Organization System, EO Emergency Ordinance, 20/2004) these inter-institutional committees act as main social coordinators in the case of emergency situations triggered by natural or anthropic hazards (RG - Romanian Government - EO, 68/2020). Under the leadership of mayors, these committees act in synergy and work as consultants: vice-mayor, ATU 3 administrative secretary, representatives of public institutions, and local economy.

The current study focuses on five types of stakeholders, each having a specific role in the risk management process: mayors, police officers, school heads, priests, and farmers. Being largely a consequence of the centralization of social life during the communist period, but also due to current legislation, many of the public institutions in Romania are organized at the communal

60 level (ATU 3): town halls, schools, police, and even the church. In this way, the leaders of these organizations are de facto stakeholders with clearly defined responsibilities, included the ones concerning disaster risk management (Ministerul Educației Naționale și Cercetării Ştiințifice, 2016; Romanian Government, 2019, 2020; Romanian Parlament, 2020): (i) majors have a decisional role in administration and public services, including parts of local finances, emergency and disaster situations, local development and territorial planning; (ii) police officers are responsible with the investigation and monitoring of criminal 
65 phenomena, take care of public order and safety of people in the administrative unit concerning in situations of disasters; (iii) school heads exercises executive management of the educational unit, in accordance with the education legislation in force, including the organization of exercises to prevent the negative effects of disasters within the educational building; (iv) priests, in addition to current sermons and duties, care for the afflicted (the poor people, widows, and orphans) and assists the parishioners in their most difficult times, including in the aftermath of disaster, giving phycological support and assist with primary care; and (v) local farmers who have a great power of influence in the Romanian community, because agriculture has a significant role in the country reported to people living in the countryside (almost 50\%) and in terms of economic benefit (Burja, 2014). Farmers have labor and organizational skills able to coordinate with their peers in the countryside in case of emergencies. In addition, their knowledge of the territory can help track the changes of the weather and the land, being much more resilient than the urban society (Wilson, 1997; Heitz et al., 2009; Šümane et al, 2018). For this reason, they are reference actors within the community and a role model, especially in rural areas.

The assessment of local stakeholder's risk perception is an important issue in exploring possibilities for improving the management of emergencies, which implies individual and social preparedness, scenario-based risk assessment, process manifestation, the first evaluation of the impact, and the recovery phase (Merz et al., 2010; Zhou et al., 2018). A low level of risk perception of local stakeholders often associated with low knowledge of causal factors and the manifestation of natural hazards (e.g., magnitude, timing, spatial distribution) have created conditions in the past for making wrong decisions that have led to increased casualties and economic losses (Kron, 2000; Oliver, 2010; Kaplan et al., 2010; Baker, 2011; Dykes and Bromhead, 2018). In Romania, the consequences of natural hazards are dramatic and are getting worse, according to model projections. In order to understand the level of preparedness of communities, there is the need to analyze stakeholders' risk perceptions.

85 The literature provides a wide spectrum of studies relating to the importance of risk perception research, analysing people's cognitive appraisal toward specific hazards (e.g., Salvati et al., 2014; Pereira et al., 2016; Fuchs et al., 2017), related to sensitive geographical settings and communities (e.g., Roder et al., 2016; Alcántara-Ayala and Moreno, 2016, Gao et al., 2020) or a combination of multiple interacting factors (e.g., Mondino et al. 2020). At the same time, several studies are referring to the importance of stakeholders' risk perception and their role in varied types of risk mitigation decisions and actions: the 90 management of contaminated sediment disposal (Sparrevik et al. 2011), safety management in construction (Zhao et al. 2016), environmental health risks (Kraaij-Dirkzwager et al., 2017), floods (Heitz et al. 2009; Hazarika et al., 2016) or multiple hazards (Mărgărint and Niculiță, 2014). However, while natural hazards are a particular threat to Romanian people, no studies attempted to understand stakeholders' role in the wake of natural hazards, nor their perceptions and preparedness. The attention devoted by scholars has concentrated only on people perceptions on a range of different natural and anthropic hazards (Grozavu 95 and Pleşcan, 2010; Comănescu and Nedelea, 2015), or specifically to earthquakes (Armaş, 2006; Creţu et al., 2010; Armaş et al., 2017) or floods (Armaş and Avram, 2009; Ceobanu and Grozavu, 2009; Armaş et al., 2015; Comănescu and Nedelea, 2016). In all these studies, remarkable low-risk perception and preparedness are underlined due to historical, social, and economic reasons. 
The current paper has been designed to investigate stakeholders' level of knowledge and cognitive appraisal of natural hazards and understand their role during emergencies. For this reason, a set of questions has been developed and administrated face to face to selected stakeholders in the rural administrative units of Iaşi metropolitan area (NE Romania). Iaşi metropolitan area is one of the largest urban and rural areas in Romania (Iftimoaei and Baciu, 2019), and due to its geographic location, geomorphologic features, and climatic settings, made this area particular fragile to climate extremes and changes, threatening the economic sustainability and development of the region. For all these reasons, Iași area can be considered as a hotspot and can serve as a comparative study for similar realities in Europe.

\section{Setting the scene: natural hazards in Iași Metropolitan Area (Romania)}

\subsection{Geographical settings}

Iași Metropolitan area is located in North-Eastern Romania, in the proximity of the border with the Republic of Moldavia (Fig.

1) and accounts for 18 communes (ATU3) situated in its proximity.

In order to have a more unitary image from the point of view of floods and landslides, we decided to add another 5 ATU3 (Costuleni, Golăieşti, Horleşti, Ţigănaşi, and Voineşti) to the 18 communes of the metropolitan area (Fig.1). As part of the Moldavian Plateau, the study area is a monoclinic hilly region, with altitudes ranging from 30 to $400 \mathrm{~m}$ a.s.l. (Niculiță et al., 2018), developed in a Miocene mudstone-marlstone lithology, with sands, sandstones, and limestones intercalations, which

115 favored a dense distribution of landslides (Mărgărint and Niculiţă, 2017; Niculiţă et al., 2019, Bălteanu et al., 2020). According to the Köppen-Geiger classification of the world climate (Kottek et al., 2006), the analyzed area is characteristic of the dry continental climate (Minea, 2013; Mărgărint and Niculiță, 2017). At Iași meteorological station (102 m a.s.l.) the mean annual temperature and the mean annual precipitation are $9.6^{\circ} \mathrm{C}$ and $559.7 \mathrm{~mm}$, respectively, from 1950 to 2006 (Croitoru and Minea, 2015). Iaşi metropolitan area is particularly vulnerable to anthropogenic hazards (Dicu and Stângă, 2013), but also to natural ones, as a direct consequence of dramatic changes in population dynamic and build-up sprawl in the surrounding settlements of Iaşi city in the last decades. After the period of socio-political adjustments following the events of 1989, with ambiguous legislation, economic stagnation, and the lack of territorial planning, Iaşi became, again, after 2000, one of the main poles of urban and economic growth in Romania (Benedek and Cristea, 2014). In the last decades, there was recorded an obvious tendency of sprawling of the built-up spaces along the main roads, even the low level of construction favourability of the lands

125 (Stoleriu, 2008). The old agricultural activities were gradually replaced by new constructions, industrial and storage spaces, by renting the lands. Individual dwellings appeared more and more on lands with erosive risk, without coherent territorial development plans, in neighborhoods with inadequate infrastructure: undersized lifeline network, the unmodernized road network that constantly generates traffic problems. Traditional occupations of the inhabitants (agriculture, vineyards, orchards, vegetable farming, and livestock) were gradually moving further and further away from the central urban pole, thus creating a permanent readjustment of the land cover and labor force (Cîmpianu and Corodescu, 2013). Interesting are the examples of 
communes that in only 11 years (between 2007 and 2017) had exceptional increased the number of inhabitants (Valea Lupului, 102.8\%; Miroslava, 93,4\%) or new constructions (Miroslava, 164,8\%; Valea Lupului, 141.4\%).

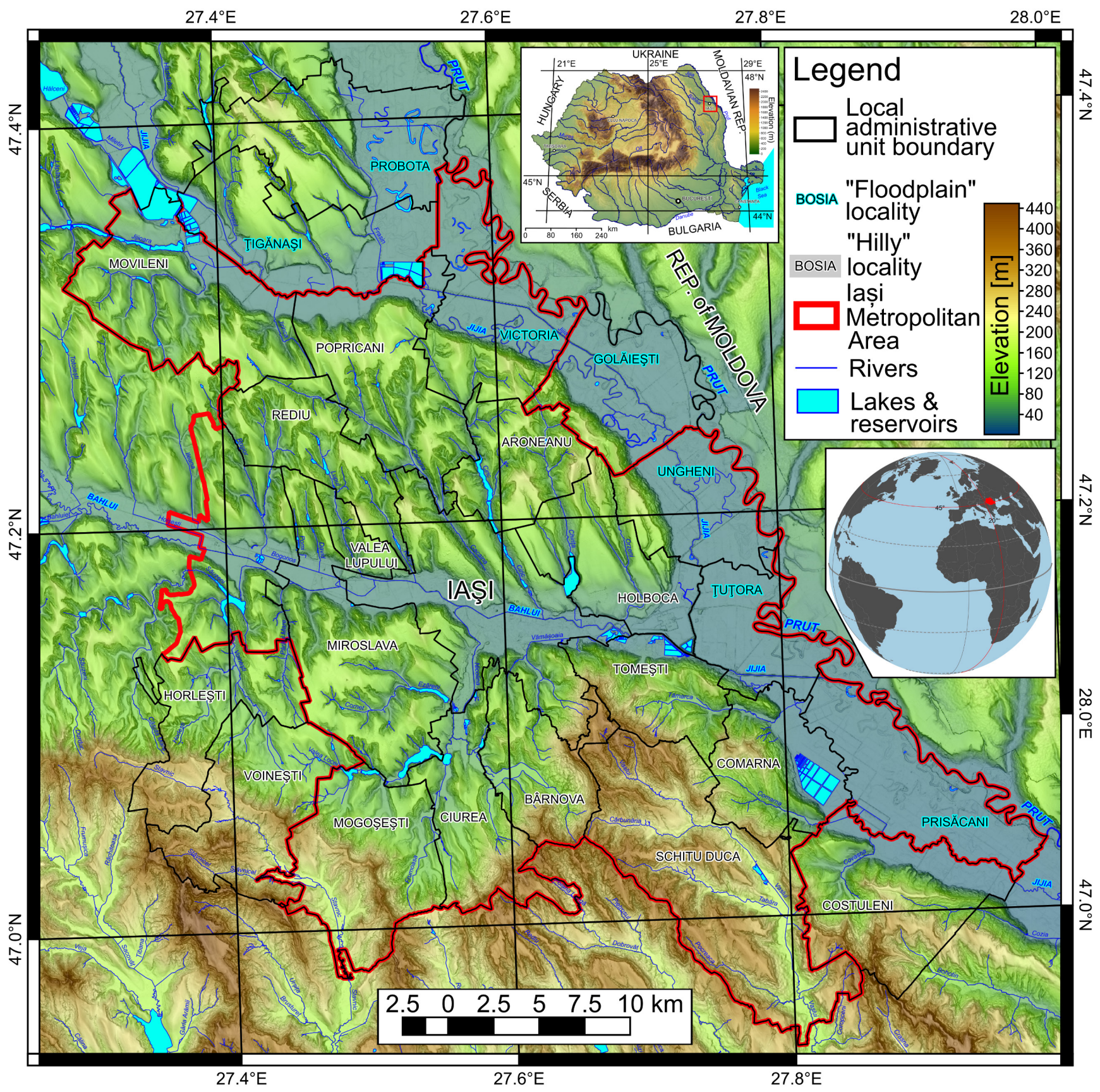

Figure 1: The geographical position of the study area.

135 The same trend is highlighted by the number of building permits issued in 2017, which in some cases (Miroslava and Valea Lupului) exceed that of the main urban center. A new peri-urban area is developing spontaneously around Iaşi City, which is 
growing rapidly but chaotically, generating severe problems related to the environment's quality and the future possibilities of landscape planning (Stoleriu, 2008). These complex changes in the recent past will create a greater degree of vulnerability of the population to natural hazards that have manifested in the study area in recent decades. A synthesis (Rotaru and Răileanu, 2009) of the damages caused in the 2000-2005 period by rains, hail, strong winds, and landslides in Iaşi County revealed losses estimated at 37 million RON (around 11.5 million Euro at that date). Also, a constant threat to the life of people and their dwelling stock is represented by earthquakes: Iaşi County was the most affected by the 7.1 MW subcrustal earthquake from 1997 in terms of total affected dwelling stock (Georgescu and Pomonis, 2008) and remain one of the most vulnerable to seismic hazard in Romania (Bunea and Atanasiu, 2014; Dutu et al., 2018)

145 In order to differentiate the administrative units and, as a consequence, different risk perception of the interviewees based on geographic location in the major landforms of the study area, the communes in which the present study was carried out have been split into two categories: (i) floodplain communes, located mainly on the major floodplains in the area (Prut, Jijia and Bahlui floodplains) and (ii) hilly communes, with a large development of slopes and associated geomorphological processes: landslides and soil erosion (Fig. 1).

\subsection{Natural hazards characterization}

Natural hazards considered in our study are droughts, rainstorms, heavy snowfall, floods, landslides, soil erosion, and earthquakes.

Droughts in NE Romania are associated with anticyclone conditions from summer and autumns, characterized by high temperature and low precipitation. The most frequent periods with drought appear in August, while the lengthiest appearing in October and the shortest in June (Mihăilă, 2006; Pelin, 2015). The impact of droughts on rural communities is high in NE Romania and can affect a wide range of activities (agriculture, forestry, livestock, water supply, industry), the quality of public health is considered as one of the main factors of rural poverty (Chiriac et al., 2005). Taking into account the intensity and multi-annual variability of droughts in the Moldavian Plateau, Cismaru et al. (2000) found that for the 1981-1998 period, the correlations between percentage losses of crops are logarithmically correlated with droughts intensity at the end of the vegetation period (usually October). In some parts of Moldavian Plateau, for the mentioned period, these losses reached up to $41-50 \%$, in the case of corn crops, and $40-43 \%$ in the case of sugar beet or alfalfa.

Rainstorms are frequent in late spring, summer, and at the beginning of autumn, especially during the summer, the majority of the precipitations coming from these events (Mihăilă, 2006). In Iași the frequency of rainstorm is up to 40 times per year, the maximum 24-hour values were $136.7 \mathrm{~mm}$ (in June 1985 when in three days at Iași the rainstorm reached $193.8 \mathrm{~mm}$ ), and the monthly cumulated values almost reached 300 mm (Mihăilă, 2006; Niculiță, 2020). In the proximity of Iași, toward the contact with the Central Moldavian Plateau, the 24-hour maximum value if even higher: at Sinești (30 km toward ESE) $185.3 \mathrm{~mm}$ in 12 hours, at Mogoșești (15 km toward SE) $154.4 \mathrm{~mm}$ and at Bârnova (10 km toward S) $167.9 \mathrm{~mm}$ (Minea 2013). Hail is a common phenomenon, associated with rainstorms, with an aleatory distribution in space and time, but with important events in 1950 and 1984, which produced important damages to agriculture (Mihăilă, 2006). 
170 The mean yearly number of snowfall days is 45 at Iași, but the yearly variation is between 16 and 70 days (Mihăilă, 2006). Heavy snowfall can have negative effects on agriculture and society when they happen very late, in April or even May, or when the intensity is very strong during winter (Mihăilă, 2006). Blizzards usually manifest from December to February (in February being the most frequent), but early (November) or late (April) events can appear (Mihăilă, 2006; Niacşu et al., 2019). At Iași there is a mean of 9 days per year, but the variation is between 0 and 22 days per year. During this phenomenon, the wind has a mean speed of 50-75 km/h, with a predominant direction from NW and $\mathrm{N}$, the maximum speed registered being $200 \mathrm{~km} / \mathrm{h}$ in 1966 (Mihăilă, 2006).

Floods are particularly frequent on Prut River, where the two remarkable ones occurred in 2008 and 2010 when thousands of hectares were covered by water and many settlements were threatened and partially evacuated (Romanescu et al., 2011a, 2011b; Romanescu, 2015). Much earlier, another event dated to 1991 has marked some great damages in Jijia River's

180 floodplain (Romanescu et al., 2017). In Bahlui catchment, the hydro-technical infrastructure has diminished the frequency and the severity of floods (Minea, 2013), which were having important negative impacts on the populations from Iaşi city before 1960 (Tufescu, 1935). The impact of major floods in the last century on settlements from NE Romania was recently depicted using detailed topographic maps: dozens of villages have partially or totally displaced in the Moldavian Plateau (Văculișteanu et al., 2019).

185 Landslides and soil erosion are common natural hazards in the study area. In the last decades, landslides have been slow movement reactivations that generated household displacements and infrastructure destructions (Niculiță et al., 2017, 2018). One of the most destructive recent events that took place near our study area was the reactivation of Pârcovaci landslide in December 1996, triggered by heavy rains and snow melting: 97 households were destroyed or heavily damaged, affecting up to 400 inhabitants (Cioacă and Dinu 2002; Rotaru and Răileanu, 2009). In a recent study, Niculiţă et al. (2018) have identified

190 and mapped a total number of 518 landslides that happened in the last century in Iaşi Metropolitan Area. They are usually reactivations of old landslides and present an obvious temporal pattern, in a strong relationship with the variability of precipitations. Their low magnitude and the fact that almost all the identified landslides happened outside populated areas show that landslides could be perceived not so dangerous by the inhabitants. But the situation could change in the future, considering permanent expansion of the built-up area (Cîmpianu and Corodescu, 2013; Iaţu and Eva, 2016) and future changes

195 in climate evolution (Niculiţă, 2020). Soil erosion is favored by the increased tendency of extreme meteorological events, fragmented topography, and the land use of the study area. These characteristics frame our study area in the most important hotspots of soil erosion in Romania (Prăvălie et al., 2020).

Earthquakes are geological hazards that are quite present in Romania. Iaşi city is located about $200 \mathrm{~km}$ distance to Vrancea region, one of the European seismic hotspots. Since 1800, 7 earthquakes with moment magnitudes (MW) above 7 were

200 registered, while the last 120 years were marked by four major events, measuring 7.1 MW (1908, 1986), 7.4 MW (1977), and 7.7 MW (1940) (Lungu et al. 2007; Mărmureanu et al., 2011). The last strong earthquake (March 4, 1977, 7.4 MW, 109 km hypocentre depth) was the cause of many socio-economic damages in Romania (exceeded 2 billion USD at that time), claiming the death of 1,578 people and injuring another 11,300 persons. At a national scale, the impact was huge: 32.897 collapsed or 
demolished dwellings, 34,582 homeless families, 763 industrial units affected, and many other damages in all sectors of the economy (Georgescu and Pomonis, 2008). Although located relatively far from the epicentral zone, Iaşi county was the most affected in Romania in terms of percentage of dwelling stock affected: $47 \%$ was affected, from which $11 \%$ destroyed, $13 \%$ of dwellings requiring strengthening, and 23\% dwellings requiring repair (Georgescu and Pomonis, 2008). In the last decades, earthquakes of over 6Mw were those from 1986, 1990, and 2004 and minor damages were reported.

\subsection{Climate trends in NE Romania}

In the 1900-2005 period, mean annual temperature in Northeastern Romania has increased by around 0.2 and $0.3^{\circ} \mathrm{C}$ (Haylock et al., 2008; Kurnik et al., 2017), while for the 1961-2007 period, the trend of the increase is between 1 and $1.2^{\circ} \mathrm{C}$ (Busuioc et al., 2010). The current and future climate changes trends, and effects for Romania are not very well studied, and the existing results based on observational and modeling data are very often contradictory (Busuioc et al., 1997; Cuculeanu et al., 2002; Busuioc et al., 2010, 2013; Croitoru and Minea, 2015; Croitoru et al., 2016), this being the motive that the European level downscaled scenarios need to be taken into account. Currently, CORDEX (COordinated Regional climate Downscaling EXperiment) framework is used for European regional forecasting at a $12.5 \mathrm{~km}$ resolution and for the RCP4.5 and RCP8.5 emission scenarios (Moss et al., 2010; van Vuuren et al., 2011), through the EURO-CORDEX initiative (Jacob et al., 2014). The interpretation of modeling on a continental scale shows for the study area a change of 2071-2100 period temperature compared to 1971-2000 period, of 2 to $5^{\circ} \mathrm{C}$ for mean annual, summer, and winter values (Jacob et al., 2014; Kurnik et al., 2017). The historical climate data show for Northeastern Romania an increase of annual mean values with up to $20 \%$ and a decrease of summer precipitations with up to 5\% (Haylock et al., 2008; Kurnik et al. 2017), although strong spatial variability is shown (Croitoru and Minea, 2015; Croitoru et al., 2016). The forecasts show a further continuation of these trends (Jacob et al., 2014; Kurnik et al., 2017). Climate change driven by anthropogenic emissions is expected to increase precipitation extremes in both wet and dry regions as it happened in the historical period, although the intensity cannot be predicted (Donat et al., 2016; Donat et al., 2017; Ingram, 2016). Anyway, the fact that the precipitation intensity will increase should be enough to alarm the authorities and the citizens (Ingram, 2016). In NE Romania, the forecasts are that precipitation extremes will increase (Jacob et al., 2014; Kurnik et al., 2017), continuing the trend of the historical data (Croitoru et al., 2016). Heatwaves are expected to be more frequent and more intense considering the increase in temperature (Velea and Bojariu, 2018). The historical trends of droughts in NE Romania are of increasing frequency but decreasing magnitude (Minea and Croitoru, 2015, 2017; Minea et al., 2016; Spinoni et al., 2015), while the forecast is of slight increase (Stagge et al., 2015). North Atlantic Circulation has a delayed effect on the spring flow (Bîrsan, 2017) in NE Romania, which will continue to remain a future trend, while the runoff should decrease (especially in summer), continuing the historical trends (Stahl et al., 2012; Croitoru and Minea, 2015). These assumptions are based on the upward trend of precipitation and evapotranspiration due to increasing temperatures (Cuculeanu and Bălteanu, 2004). The minimum discharge will decrease, and the water deficits will increase

235 (Forzieri et al., 2014). The flood magnitude instead will increase in NE Romania (Alfieri et al., 2015; Reker et al., 2017), so probably the number of deaths in Romania will continue to be one of the biggest in Europe (Vanneuville et al., 2017). 


\section{Data collection and methods}

Local stakeholders have been selected representing different characteristics in terms of power, legitimacy, and urgency (Mitchell et al., 1997; Mainardes et al., 2012). Further, the dominant stakeholders (mayors, police officers), discretionary stakeholders (farmers), and dormant stakeholders (professors and priests) have been selected. Semi-structured in-depth interviews have been run from March 2017 until October 2018 involving 118 people: 23 mayors, 27 farmers, 25 priests, 21 police chiefs, and 22 school heads. (Fig. 1). As in many other countries, in Romania, public institutions are organized at administrative levels, village/town halls, schools, police headquarters. The leaders of these institutions (mayors, police chiefs and school heads, and in few cases, their deputies) were recruited directly to participate in the present study. Priests and local entrepreneurs (farmers) were randomly selected and interviewed on-site.

The questionnaire was organized into two parts: the first with pre-defined questions regarding the assessment of risk perception induced by natural hazards: level of threat, personal experience, level of knowledge, level of preparedness, risk management, communication, and trust (Table A1, Appendix) and a second part in which discussions have been focussed on environmental and hazardous phenomena that threaten the places where they live and work. Interviews were run from 30 to 50 minutes according to the desire of the participant to expand the open questions with his/her personal experience. In most of the cases, there were constructive discussions, some stakeholders inviting other members of the community (especially the mayors) into the dialogues considering it an enriching approach for the community.

There is a clear gender imbalance in the sample of stakeholders considered for the interviews (Fig. 2). This is due to the specificity of certain professions in Romania (priests are exclusively men, while police officers predominantly) or the perpetuation of older mentalities regarding the occupation of positions at the top of public administration (the case of mayors $100 \%$ men). Only for school heads, we found a balanced situation: $63 \%$ were women. The majority of the stakeholders have a university degree, being a mandatory requirement for school heads, priests, and police officers. A large proportion of stakeholders (88\%) live in the area where they work (same community or neighborhood communities), and this could suggest an amplification of perception of high-probability risks and reducing low-probability ones (Bernardo, 2013). The age distribution is skewed toward older persons, especially in the case of mayors (mean age 53.6 years) or school heads (49.2 years) in contrast with a younger age of policemen (39.4 years).

To test some assumptions, we formulated the following questions:

Q1: Is there a dependency relationship between the threats of different natural hazards?

Although the selected stakeholders have different roles within the communities and a different timing in the evolution and management of the events related to natural hazards, all of them bear extra responsibility (legislative, educational, communicational, and moral) compared to the lay public. In this sense, we stated the second hypothesis.

Q2: Do different stakeholders have different perceptions and preparedness level according to a set of natural hazards? 
Since Iaşi Metropolitan Area is situated in two main geomorphological settings (hilly areas and floodplains) and during the last decades, there have been registered localized hazards (such as landslides in hilly areas and floods in floodplains), this factor could influence the risk perception. As a consequence, another question was formulated.

Q3: Do geographical and topographical characteristics of locations affect stakeholder's risk perception of different natural hazards?
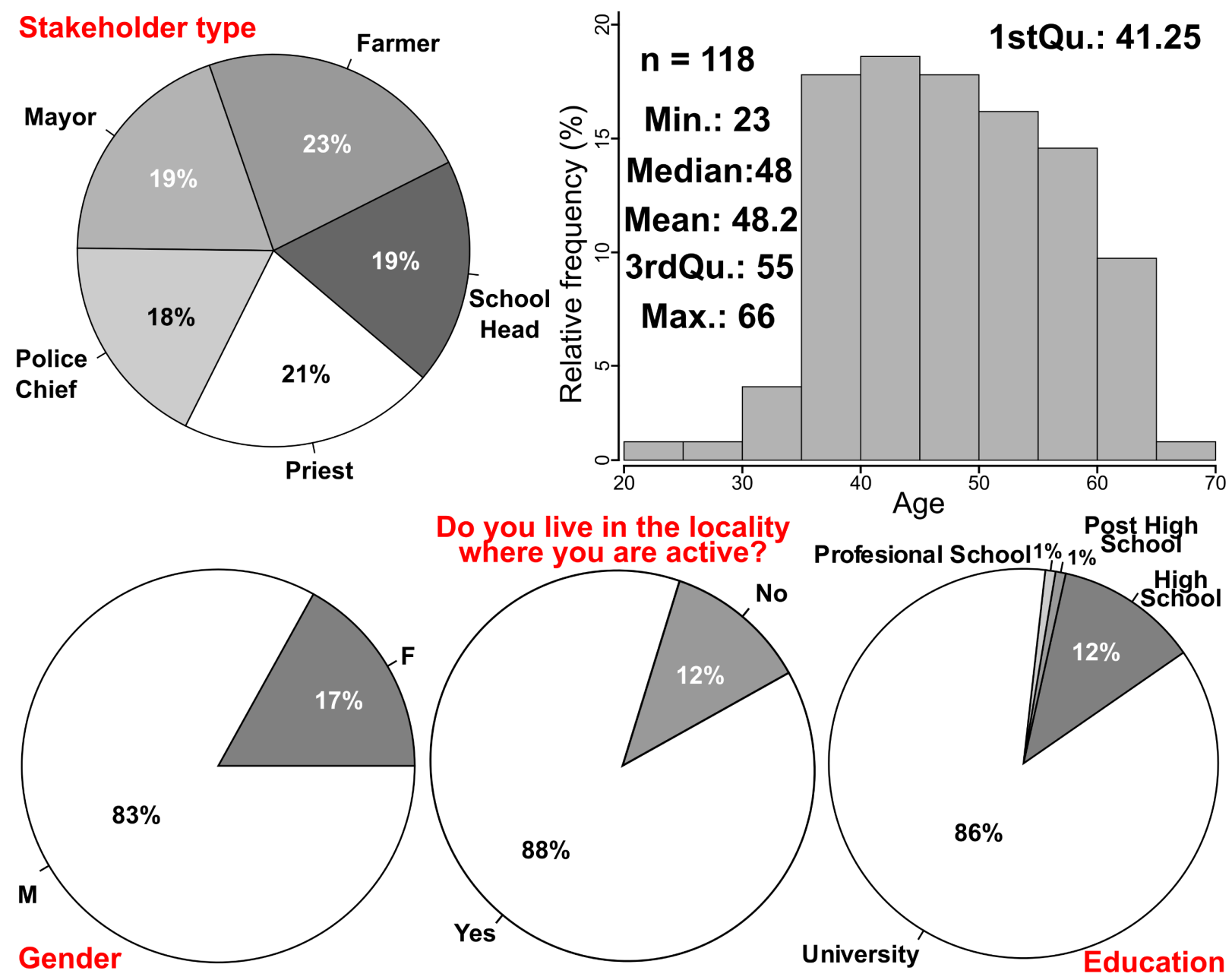

Figure 2: Descriptive statistics of interviewees.

\subsection{Statistical analysis}

Data coding was performed using a tabular data application (Open Office Calc) by assigning codes from 1 to 5 for the Likert scale data and from 0 to 1 for dichotomous responses. The continuous variables were coded using numbers. After the coding, the raw data was exported to $\mathrm{R}$ stat (R Core Team, 2018), where the data was manipulated to obtain the format required by the specific functions used to analyze them. The statistical analysis was performed in three main steps (Openheim, 2000): 
280 (i) first, the univariate analysis was performed by plotting on the Likert or arithmetic scales the sample distributions in order to have a first overview (descriptive statistics) of the data. Also, we have chosen to comply with the standard statistical assumptions (especially regarding the failure of parametric statistics in the case of extreme values of ordinal data and unequal interval scales, Baker et al., 1966, Armstrong, 1981) and use both univariate and bivariate analysis with graphical analysis to provide a more in-depth analysis (Knapp, 1990; Mircioiu and Atkinson, 2017). Also, we avoided considering Likert data as nominal categories since the ordering will be lost (Agresti, 2010; Mangiafico, 2016).

(ii) secondly, the bivariate analysis consisted of computing the cross-tabulation and various independence and association measures between the variables. First of all, it has been tested the independence of the responses toward the risks involved in the study for the stakeholders' categories and, after that, association tests for the assessment of the significance of stakeholder type and other categorical variables. Kruskal-Wallis rank-sum test was used to assess if there are differences in the responses (Magnifiaco, 2016) for every category of risks and natural risks and decedent type, village, commune, flooded or non-flooded, age, gender, education. When the dependence exists (the null hypothesis is rejected), the statistic Freeman's epsilon-squared was used to assess the association's strength between one ordinal variable and one nominal variable (Mangiafico, 2016). This statistic ranges from 0 to 1 , with 0 indicating no association and 1 indicating perfect association. Values bigger than 0.5 were regarded in our case as a measure of powerful association in the presence of dependence. This association measure was computed using the epsilonSquared() function from the rcompanion R package (Mangiafico, 2016).

(iii) finally, we applied a multivariate method, correspondence analysis for those questions and risks that were found conclusive in the bivariate analysis step.

Besides, CA (Correspondence Analysis) graphical methods have been applied for exploring the relationships between variables in contingency tables (Greenacre, 2007). The method's theory is straightforward, based on the singular value decomposition

300 of the contingency table's matrix data structure. We have chosen this method because it describes our data graphically in terms of showing the differences between stakeholder types or other categorical variables, especially for those with big Freeman's epsilon-squared values. The Likert scale with the answer to the question is considered the dependent variable, and the variants of the response or the categories of stakeholders or other associated categorical data (flooded or non-flooded communes) are the independent data. The column variables (e.g., stakeholder type) are displayed as oriented vectors, while the Likert scale counts are displayed as dots. The orientation of the stakeholder type vector toward one of the axes shows its contribution to that axis's variance. If the angle between the vector and the lines is $45^{\circ}$, then the contributions to the two axes are the same, while if the angle is smaller toward a certain axis, the greater the contribution to the variance of that axis is. The length of the arrow vectors is proportional to their contribution to the two-dimensional solution. Since we have an ordered variable, and the distances between the categories are not the same, there is no logic to take into account the distances along the axes of the CA plot and to make comparisons (although this type of plot allow this, in the sense that the axes are scaled to a common scale). 


\section{Results}

\subsection{The level of threat}

The first question addressed to the interviewees was designed to assess the main socio-economic and environmental factors which could affect the communities' quality of life. The majority of stakeholders (61\%) consider that the level of development is the main factor that can threaten the quality of life in their territory (Fig. 3). It follows the risks induced by natural hazards ( $57 \%$ of responses), climate change (40\%), criminality (37\%), environmental pollution (27\%), and technological risks ( $8 \%$ ).

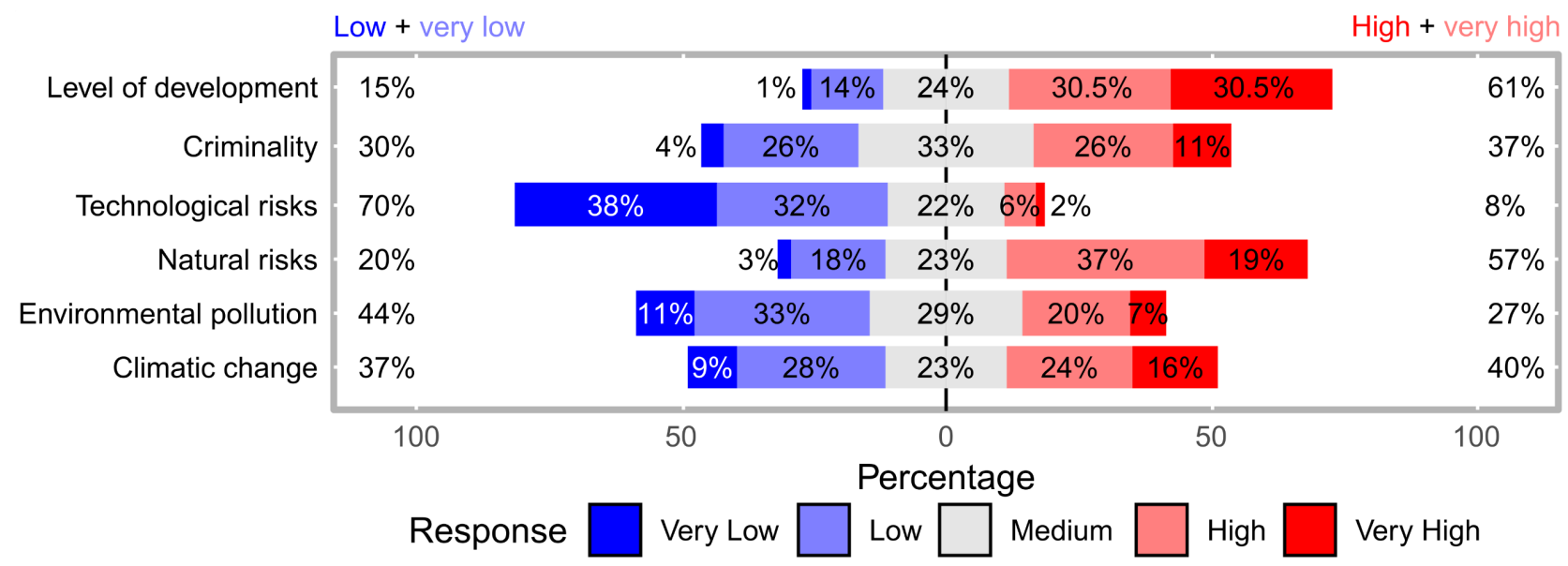

Figure 3: Likert plot of the responses regarding the perception of the factors that can threaten the local community.

Generally, the stakeholders that participated to the present survey consider droughts as the most threatening natural hazard both for their communities but also for them personally (Fig. 4).

Water scarcity is a direct consequence of the continental climate of the region that affected the agricultural economy of NorthEastern Romania for centuries (Mărgărint and Niculiţă, 2016; Niculiţă et al., 2020). Many stakeholders reported a drastic reduction in the number of cattle, which, in the driest years, can reach $80 \%$ of the total animals of the households in the villages. "There are ten years since I had serious problems every year. I achieved a special car-tanker to get water for livestock. And very little remains for vegetable crops. I get water from the reservoir (5 kilometers away), and I don't know what will happen when it disappears." (farmer, 35 years, managing 300 hectares of agricultural land and 35 cows. They also consider that this hazard will affect their communities for many years from now. Alongside the dramatic reduction of agricultural production, the most dangerous problems occur regarding livestock).

Earthquakes represent the second threatening hazard. The memory of the 1977 earthquake, when Iaşi County registered the highest number of buildings affected in Romania (Georgescu and Pomonis, 2008) is still vivid in the memory of many stakeholders. Although the norms in constructions were strongly upgraded after this event, after 1989, the discipline in buildings decreased suddenly due to the lack of legislation. How many dwellings have been built up in the last years is not far from the knowledge of the interviewees and, from this point of view, many raised serious questions regarding the resistance 
https://doi.org/10.5194/nhess-2021-37

Preprint. Discussion started: 4 February 2021

(c) Author(s) 2021. CC BY 4.0 License.

of the new constructions. "Many who bought new homes think they are new and strong, but at the next big earthquake, they will find that they were built just to be sold." (mayor, 58 years, personally affected by the 1977 earthquake). The population's level of dissatisfaction is constantly increasing concerning public works, transportation, and the environment. Considering that any significant event did not trigger these permanent stressors, the real situation of risks associated with natural hazards can be much more profound, almost unknown to many of the inhabitants and their leaders.

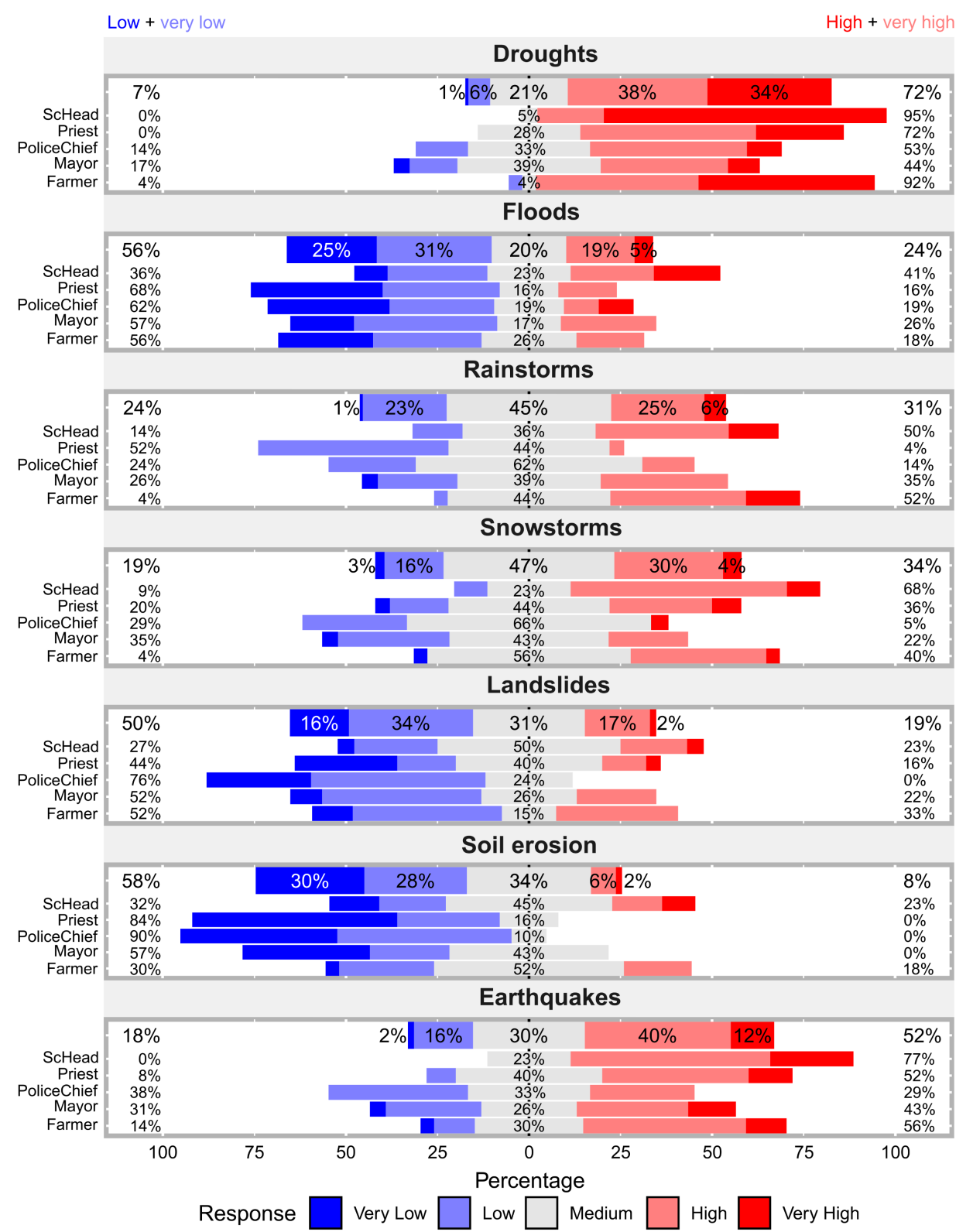

340 Figure 4: Likert plot of the responses regarding the perception of the natural hazards that can be a threat for the local community, for every natural hazard, and every stakeholder type. 
A middle position is occupied by the hazards which registered a higher frequency: rainstorms and snowstorms had a growing trend in the last decade in the study area and, as a consequence, their impact on communities is quite essential. During the year, the strongest storms occur in late spring and summer. In some cases accompanied by hail, the most significant damages are recorded in agriculture and in newly built areas that do not have an adequate drainage infrastructure. When they have a large area of development, they can affect the transports, trigger soil erosion, and lead to the increase of the lower order hydrographic network flows, leading to the destruction of the bridges, the siltation of the canals, etc. These issues were invoked as the most pressing by farmers and mayors, and police chiefs. "I am here for few years. In the center of the locality, there are no problems, there is asphalt on the street, but towards the valley, those who have moved to the house in the last four years live a nightmare every time it rains. The road is muddy and becomes impassable." (a police officer in a settlement with many new dwellings, 34 years).

Climate-related hazards that have a relatively low temporal frequency, like floods, landslides, and soil erosion, are perceived as imposing a low threat, in general. The landslide risk is high in hilly regions of NE Romania (Micu et al., 2017, Mărgărint and Niculiţă, 2017). In the last century, one of the most significant events inside the settlements took place 50 years ago in a succession of years with high precipitations (Pujină, 2008). With few exceptions, the memory of those events seems to erase. But the risk is still high, and people will face again with landslide reactivations in the years with the same increased pattern of precipitations (Niculiţă, 2020). There is a lack of prevention behavior in terms of recent expansions of built areas due to several factors: investors' desire to build and sell, lack of knowledge and awareness of the danger of those who buy, and those who should take decisions regarding the expansion of built-up areas. "In our commune, the landslide risk has been solved: we have the study regarding landslide hazard and risk in an updated form, so we are in line with the legislation." (mayor of a commune affected by landslides in 1969-1972, 66 years).

The outputs of The Kruskal-Wallis rank-sum test and Freeman's epsilon-squared statistics show correlations among every category of natural risks and a set of socio-economic and geographic variables (for further results, see Table A3 of the Appendix). The most significant differences are in stakeholder type (answering the second research question), gender, age, and spatial localization, and geomorphological context. At the same time, education does not influence the response. The results indicate that the risk perception is dependent on stakeholder types, which partially confirms the third research hypothesis. In addition, it has been found that the age of the respondents is an essential factor regarding certain risks (Table A2, Appendix) because some of them might be born after certain important hazard events such as the 1977 earthquake, 43 years ago, or the landslides events such as those between the ' 70 and the ' 80 (Niculiță et al., 2017, 2018). For floods, climatic hazards, and soil erosion, it seems that younger respondents are more aware.

The CA contribution biplot for Question 1 from Fig.5, is showing the correspondence between the perceived role of natural hazards as threats to the local community by different stakeholder type, considering the first two dimensions, that sum $96,8 \%$ of the variance. Police chiefs and priests who perceive natural hazards as low and medium threats, mayors and farmers perceive them as high threats, and school heads that perceive them as high threats. The explanation of the low perception of hazards as 
threats to the community's quality of life in the case of priests and police chiefs is given by their relative low knowledge of natural hazards, given by their profession. School heads, mayors, and farmers have a high level of awareness associated with the threats for the quality of life of the following factors: level of development (91\% of school heads), natural risks ( $82 \%$ of school heads and $81 \%$ of farmers) and climatic change (78\% of farmers, $55 \%$ of school heads). The exception is related to technological risks, given the predominant rural background of the communities. Priests and police chiefs, in general, expressed a low level of perception regarding the threats to local communities, with some exceptions: e.g., police chiefs regarding criminality, which is their duty (the same threat is seen by school heads, in association with their high level of childcare).

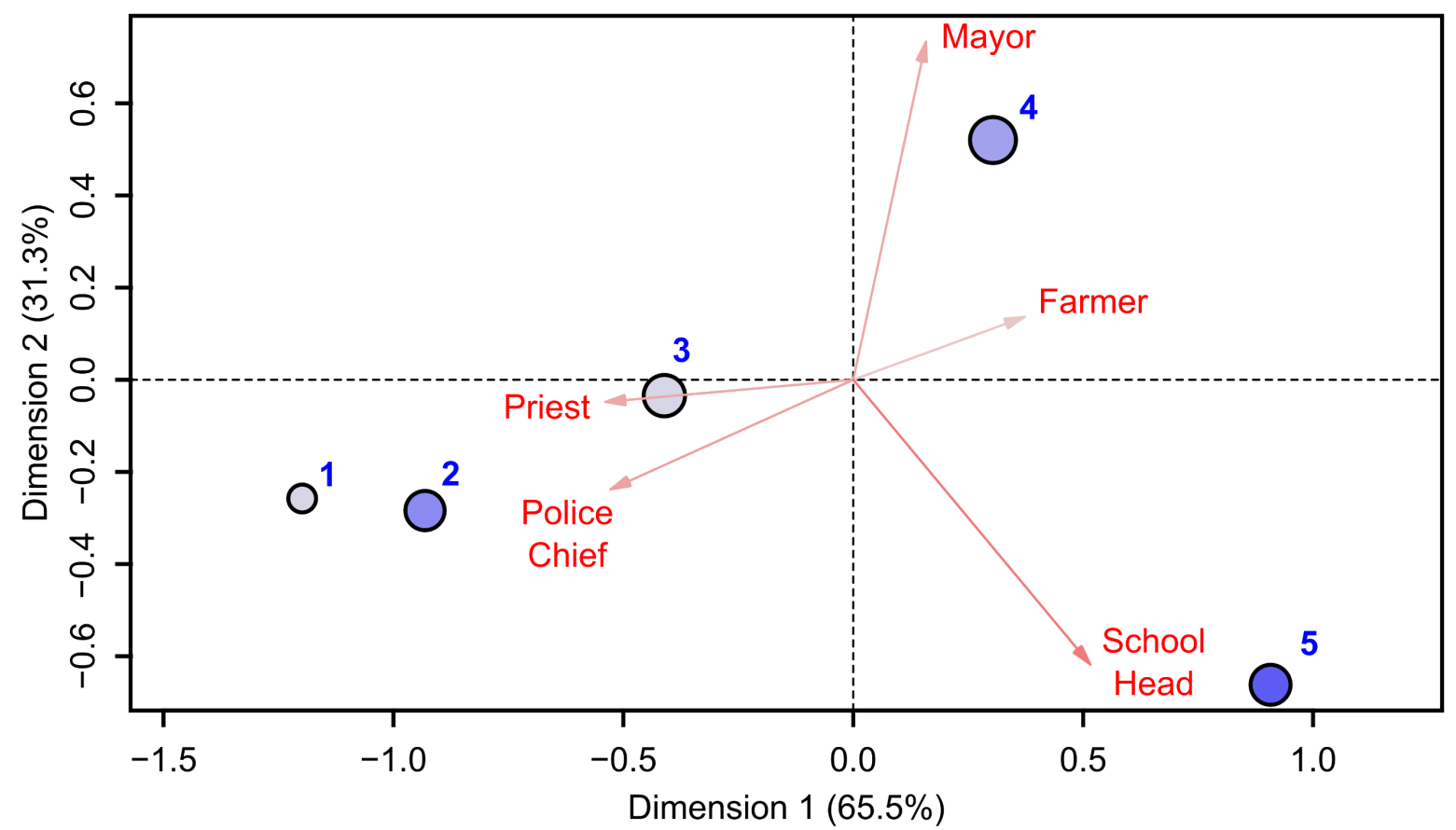

385 Figure 5: CA contribution biplot for the natural hazards' role as threats for the community's quality life as perceived by the stakeholders according to their type.

The highest values of the perceived threat associated with droughts have been registered in the case of school heads (95\%) and farmers (93\%) who expressed a great concern compared to the other stakeholders. Also, the earthquakes are seen as a significant threat by school heads (77\%), farmers (56\%), and priests (52\%). By interpreting the enlarged discussions during the interview, this could be considered as a consequence of still lively memories of the 1977Vranceaearthquake (Armaş, 2006), a social trauma of Romanian people, but also to present-day other factors: (i) a high vulnerability characterizes the majority of institutional buildings (especially schools and churches) to earthquakes (Mosoarca and Gioncu, 2013; Albulescu et al., 2020) and (ii) the frequent exercises for the improvement of the earthquake preparedness (in schools usually these exercises take place annually). The problem of the vulnerability of old buildings in Romania represents a constant public and scientific debate 
(Armaş, 2012; Banica et al., 2017) and, in this sense, we also raise on this occasion an alarm signal regarding the need for essential investments in the modernization of public spaces in urban and rural areas in Romania.

From these general results, significant differences have been recorded among the two geomorphological types of the administrative units (Fig. 1 and Fig. 6): floodplain administrative units (FAU) and hilly administrative units (HAU).

The results highlight that stakeholders have different levels of perception related to different hazards, according to the main past events that have been recorded in the last decades: in the floodplain administrative units (FAU in Fig. 6) there is a significantly higher degree of awareness concerning flood risk and possible threats, while in the hilly administrative units (HAU) the level of threat associated to landslides and soil erosion is higher than in the FAU.

Low + very low

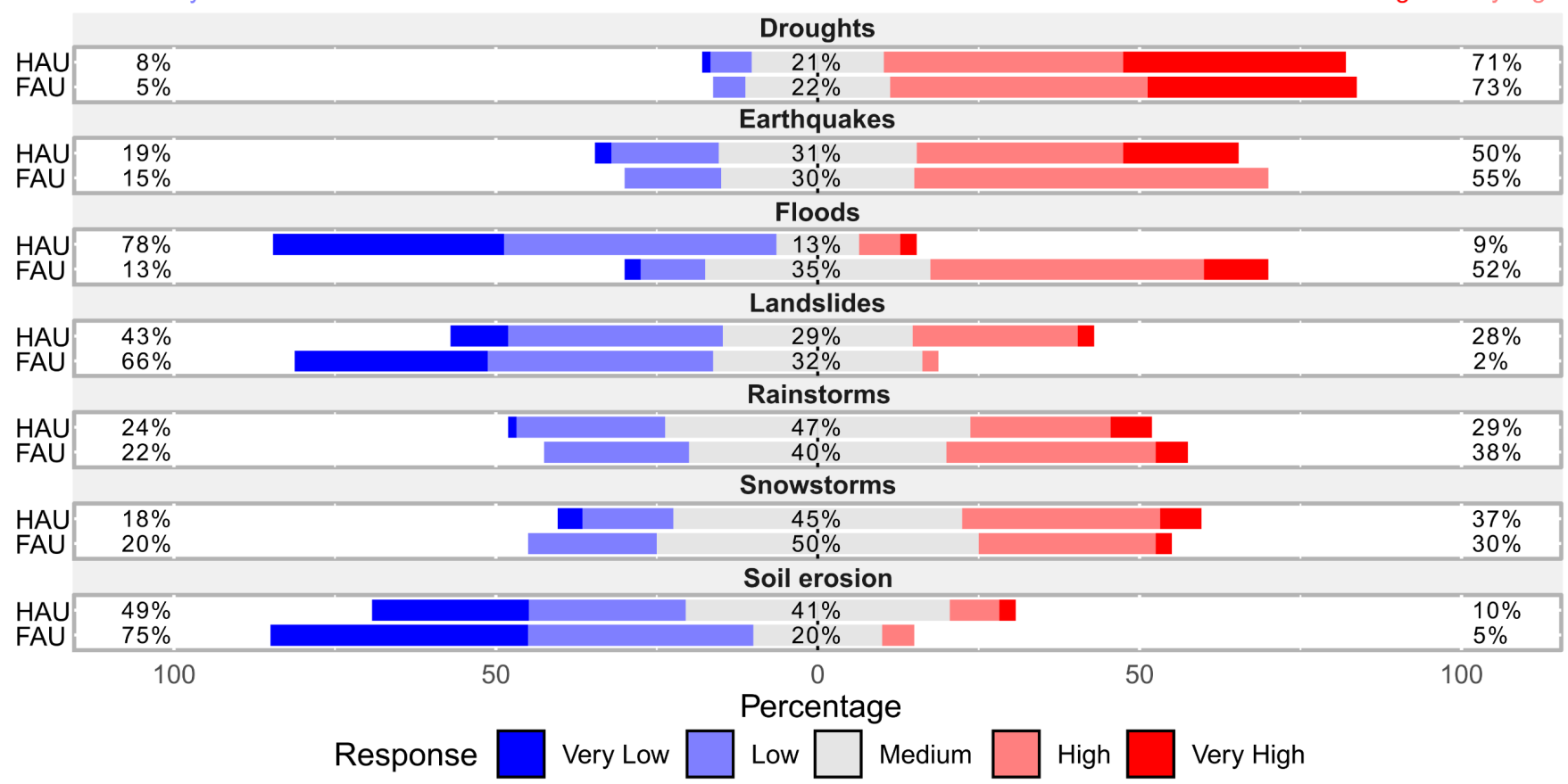

Figure 6: Stakeholders level of threat of natural hazard in relation to the dominant geomorphological landforms of administrative units (AU): floodplain (FAU) and hilly (HAU).

Again, droughts are the most life-changing natural hazards with the highest likelihood of occurrence. Rainstorms, snowstorms, and earthquakes follow them. A lower level of probability was assigned to soil erosion, landslides, and floods (Fig. 7). But here, there are important differences, depending on the geomorphological type of the locality. The stakeholders who come from floodplain settlements have indicated a higher probability for floods than the others (HAU stakeholders) and a lower probability for landslides and soil erosion.

The main geomorphological characteristics which can influence different hazardous processes and the distance to the potential risk areas constitute important factors of how different people perceive different risks (Bickerstaff and Walker, 2001; Heitz et al., 2009; Gao et al., 2020). Some natural hazards affect large areas (droughts, earthquakes, or snowstorms), while others (e.g., landslides, floods) are spatially concentrated in direct relation to topography characteristics at the local scale. From this point 
https://doi.org/10.5194/nhess-2021-37

Preprint. Discussion started: 4 February 2021

(C) Author(s) 2021. CC BY 4.0 License.
Natural Hazards and Earth System Sciences

Discussions

415 of view, the settlements from the study area, as part of the Moldavian Plateau, have been constantly affected by landslides and floods (Văculişteanu et al., 2019), and their consequences are found in the answers given by the interviewees. Table A1 of the Appendix (Q2 and column 6) and Fig. 6 shows that the geomorphological context of the area where the stakeholder works is important in its perception regarding floods and landslide risk. These results are seen in the context of a social trauma of the inhabitants managed by the stakeholders during the evacuations of some settlements along Prut Valley in 2008 and 2010 . Due

420 to the risk of flooding of the inhabited areas, in July 2008, over 3000 inhabitants from Iaşi County, including Victoria, Ungheni, and Ţuţora ATU3 (Fig. 1), were evacuated (Ziarul de Iaşi, 2008).

Low + very low

High + very high

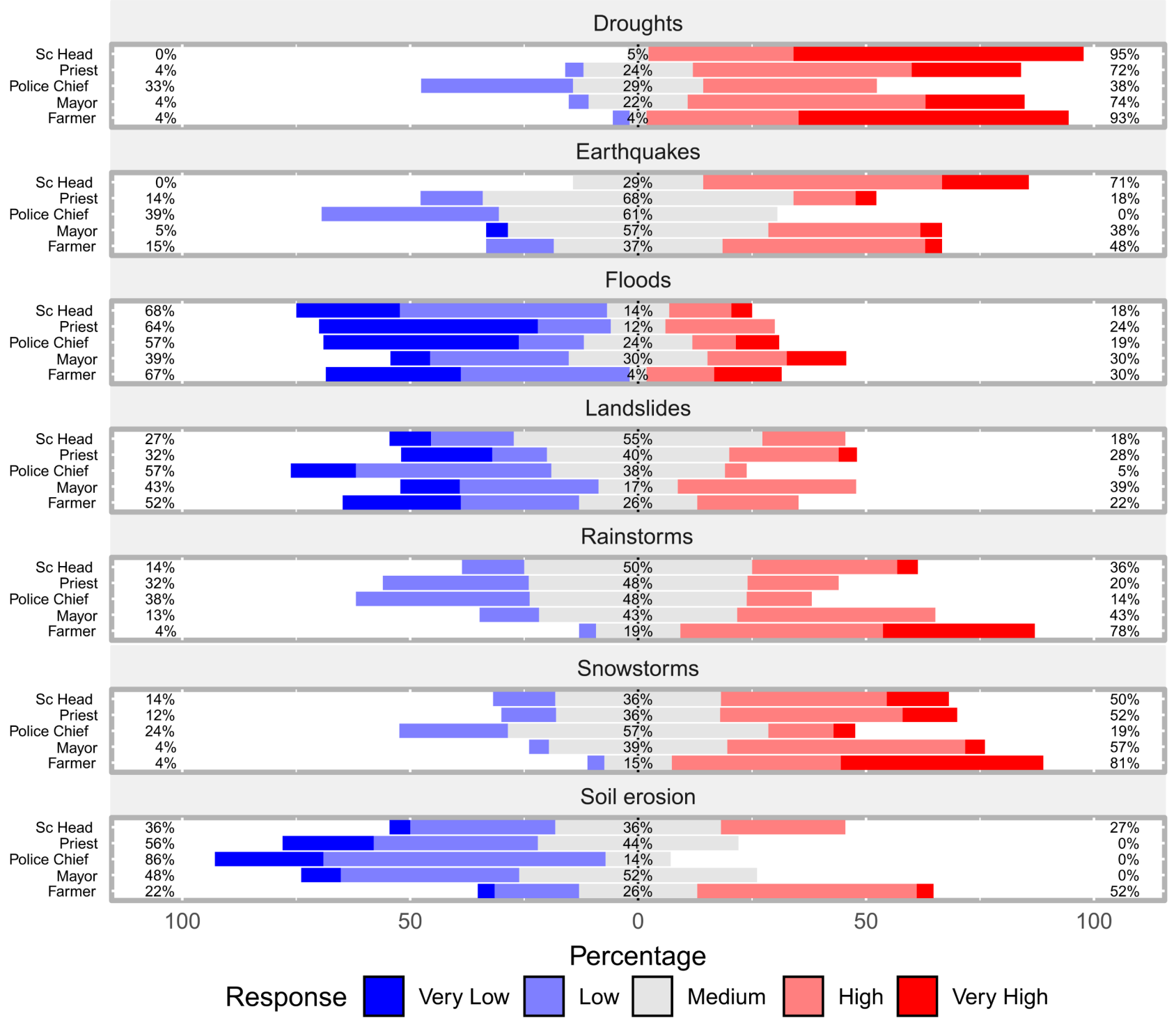

Figure 7: Likert plot of the responses regarding stakeholders' perceived likelihood of different natural hazards. 
https://doi.org/10.5194/nhess-2021-37

Preprint. Discussion started: 4 February 2021

(C) Author(s) 2021. CC BY 4.0 License.
Natural Hazards

and Earth System

Sciences

Discussions

Concerning the likelihood of occurrence of natural hazards (the fifth question), some types of natural hazards are perceived to increase in the near future, especially climatic induced hazards: droughts (86\%), rainstorms (68\%), and snowstorms (64\%). Landslides and soil erosion are perceived as not increasing, while for earthquakes, the results are balanced.

\subsection{Personal experience and knowledge}

Personal experience is one of the most critical factors influencing risk perception (Weber, 2006; Van der Linden, 2014; Knuth et al., 2015; Öhman, 2017). The study participants indicated that they were affected mainly by droughts, rainstorms, and

430 snowstorms, with farmers bearing the major costs (Fig. 8). A large proportion of them was affected by droughts (93\%), rainstorms $(78 \%)$, snowstorms, and soil erosion (48\%). Stakeholders are affected by natural hazards according to their activities and responsibilities in their daily life, exposing them to different vulnerabilities.

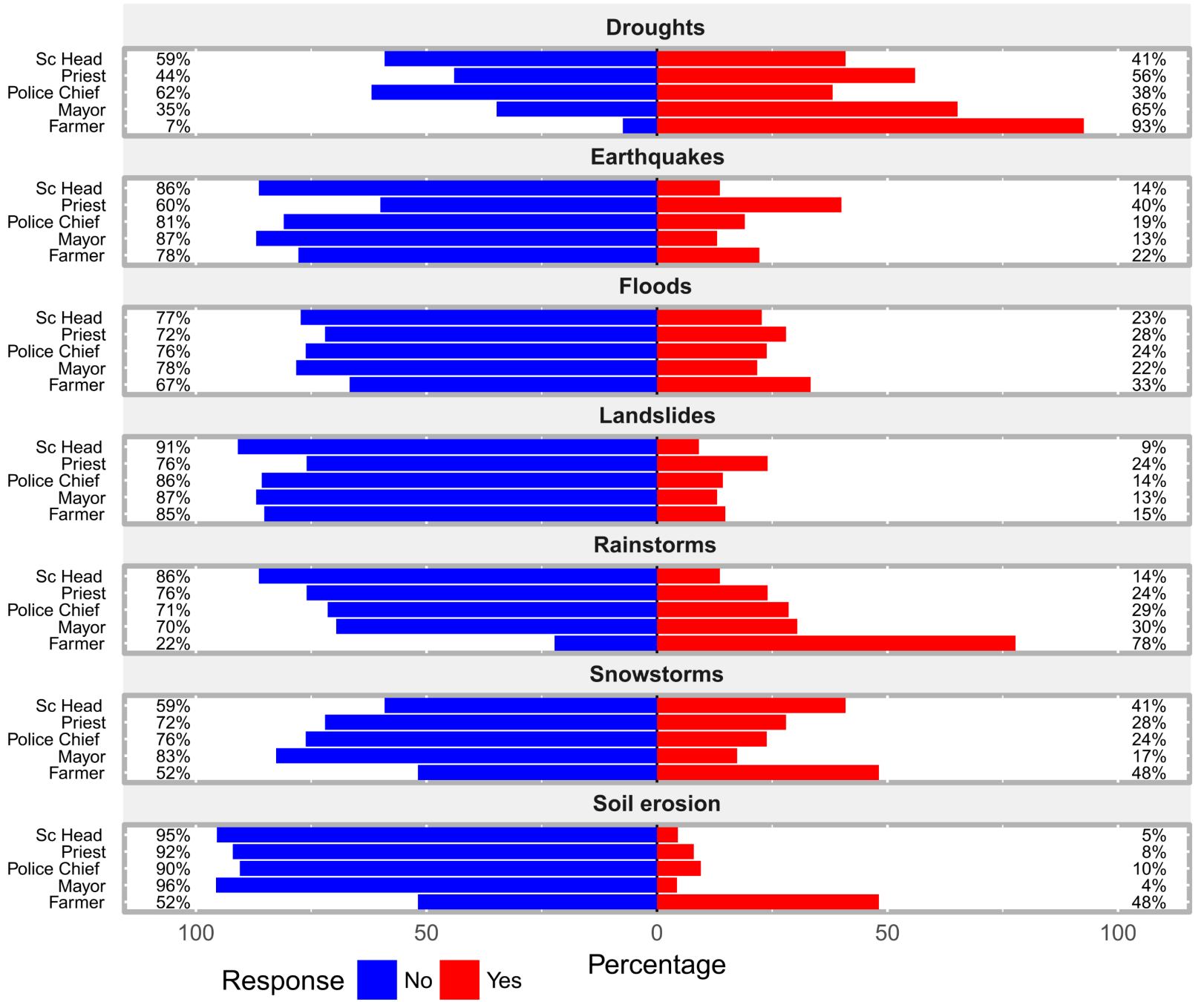

Figure 8: Stakeholders' past experiences of natural hazards. 
435 The other stakeholders were affected in a smaller measure by soil erosion. This process can generally pose problems only to those who directly connect with the land, which affects lesser the build-up areas. It is shown that experience is higher with age, especially for the analysis with the earthquake occurrence. These are disasters that, for their high magnitude, can be impressed vividly in people's memory. Their role in disaster risk management and coordination allows them to remember the most significant events they served the community. In contrast, slow onset events (e.g., droughts or soil erosion) can disappear quickly.

The knowledge of participants about natural hazards has been asked through several sub-questions. Stakeholders get information differently about the probability of occurrence and the severity of these events. The majority get information from the TV/radio (82\%), friends/family and community peers (60\%), and social networks on the internet (53\%). The more official channels are the least represented with national information initiatives (47\%), school (44\%), local administration (41\%), and volunteer associations (40\%). Looking at the triggering factors of those events, stakeholders mentioned all sub-sections from the questionnaire (Table A1, Appendix) that they consider having an important influence on the negative impact of natural hazards. Some exceptions have been registered for $57 \%$ of mayors who responded that uncontrolled urbanization and unmanaged land use planning are not influencing the occurrence of any hazard. Local administration is controlling the land use planning, and, in any case, this might be the cause of negative consequences derived by climate extremes and geological movements.

The majority of priests and mayors do not consider that climate change can exacerbate the negative consequences of natural hazards $(56 \%$ and $22 \%$ of them indicated "low" and "very low" respectively. Among the solutions to avoid the negative consequences of natural hazards, results indicated a uniform answer among all stakeholders, except the compensation scheme for the victims especially marked from mayors. Financial compensation schemes represent a particularly neuralgic issue in the post-communist society of Romania. Many interviewees highlighted that these compensations could be an encouragement of non-compliance with the law, especially regarding unauthorized constructions on lands at risk of floods and landslides.

\subsection{The level of preparedness}

The level of preparedness was investigated individually, and regarding the community, they belong. Overall, the results indicate a low level of preparedness in the case of all the natural hazards discussed. The lowest ranks were given to soil erosion (64\%), droughts (58\%), earthquakes and landslides (55\%), floods (52\%), rainstorms (50\%), and snowstorms (35\%). It seems that, despite a low level of readiness, stakeholders feel a bit more prepared to withstand the consequences of storms and floods. Snowstorms affect the communities in winter (and exceptionally in spring, the case of April 2018), and agriculture do not suffer. Life in rural areas can be more comfortable compared with urban areas. In Romania, after the recent intense snowstorms such as those from January 2008 (Georgescu et al., 2009) or January-February 2012 (Bălteanu et al., 2013), rural settlements

465 have been endowed with specialized equipment in rapid intervention, especially in the case of roads, and these endowments seem to improve the respondents' concerns. 
Similarly, the existing embankments along rivers (Prut, Jijia, and Bahlui) have often been invoked during discussions as ensuring a relatively good level of protection, especially of built-up areas. The lower level of preparedness is associated with soil erosion and landslides, for which many stakeholders declared their lack of knowledge concerning the processes themselves and related protective measures. The results of the survey made us accept the second hypothesis, which states that the level of preparedness depends on the risk type.

The same pattern of the answers has been registered in the case of the assessment of the preparedness level of the communities. However, preparedness was low, and stakeholders affirmed strongly that by good training and knowledge of natural hazards occurrence and mitigation practices, their and community preparedness could increase. Question 11 (How much do you think that your personal knowledge might increase the level of preparedness of your community? Table A1 of the Appendix) reveal significant differences among stakeholders; while in the case of school heads, "high" and "very high" responses reached 95\%, for police chiefs the percentage of the same responses dropped to $14 \%$. Intermediate values have been recorded for the other stakeholders: "high" and "very high" answers were given by $67 \%$ of farmers, $56 \%$ of priests, and $39 \%$ of mayors. Police chiefs and mayors are responsible for risk management during an emergency, and for them, preparedness is at the base of the training. For this reason, they might think that their role is the management of situations and, in any case, is the responsibility of individuals. School heads who have the obligation of small infants feel that individual preparedness is the key to successful disaster management, evacuation, and recovery. In this regard, participation in simulation evacuations is a crucial step for a positive disaster outcome. Most of the stakeholders declared that they had participated, especially in the simulations concerning earthquakes, and few of them indicated other specific hazards (e.g., fires). Seventy-two of stakeholders (61\%) declared that they participated in simulations in the last years, most of them to earthquake simulations (especially school heads and mayors). Stakeholders from floodplains communes stated participation in flood simulations. In a particular case (Aroneanu settlement, located close to Iaşi International Airport), stakeholders participated in a technological disaster exercise (aircraft crash). The period elapsed since the last simulation varies from few months to over ten years, the most recent being mostly declared by the school heads.

490 Some of the most representative CA biplots represent the position of stakeholder types in the case of preparedness to cope with different types of natural hazards (Fig. 9 and 10).

The same differentiated pattern of the stakeholder responses was recorded in the case of the level of their communities' preparedness.

\subsection{Risk management, trust, and communication}

495 Several factors have been listed (Fig. 11) and discussed as representing long term solutions to improve current risk management plans.

Most of the participants agreed with all the items proposed. On the other side, priests seemed to be the most pessimistic, especially in terms of predictability, people's preparedness, intervention, and recovery capacity. Again, the role of trust in depicting a negative situation in which stakeholders evidenced low trust on mitigation and management measures (Fig. 12). 
https://doi.org/10.5194/nhess-2021-37

Preprint. Discussion started: 4 February 2021

(c) Author(s) 2021. CC BY 4.0 License.

500 As mayors followed the same trend, it is plausible to think that they delegate the responsibility during emergencies to other institutions, imputing ineffective planning and organization.
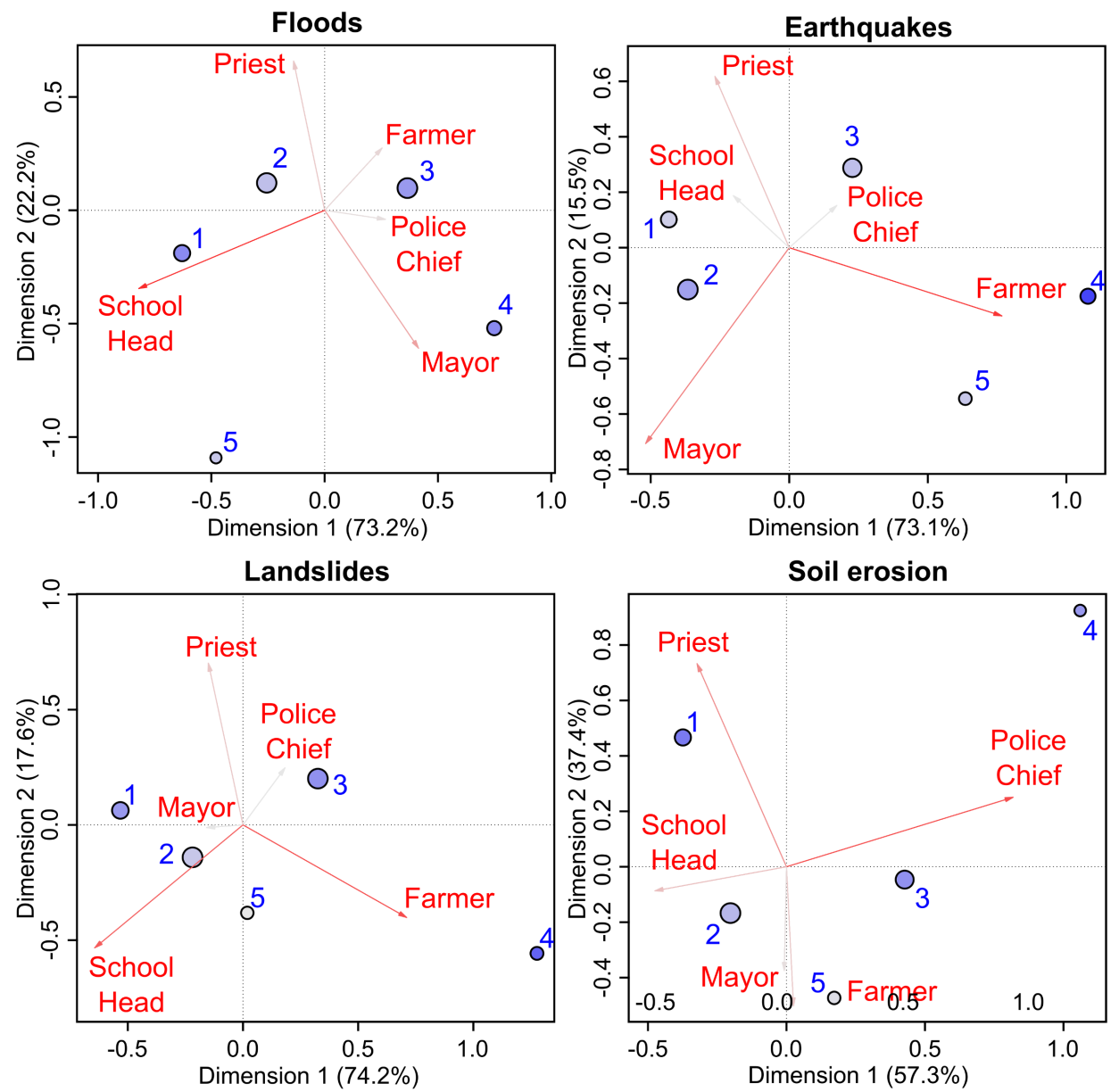

Figure 9: CA contribution biplots for perceived personal preparedness of different stakeholders for floods, earthquakes, landslides, and soil erosion.

Question 16 ("In your judgment, how much are the opinions of the following actors taken into account in the decisions about measures to adopt for preventing or reducing damage from natural hazards phenomena?") presents a grouping of "high" and "very high" responses around $70 \%$ for followings sub-sections: local communities, technicians/engineers, elective representatives at local and national levels. A lower percentage (34\% of "high" and "very high" responses) has been registered for the sub-section "environmental organizations." Among stakeholder types, we should highlight the higher percentages of "low" and "very low" responses in the following cases: priests for "elective representatives at the local level" (16\%) and "technicians/engineers" (16\%), school heads (50\%) and mayors (43\%) for "environmental organizations," farmers for "local communities" (16\%), and "state elective representatives" (26\%). 

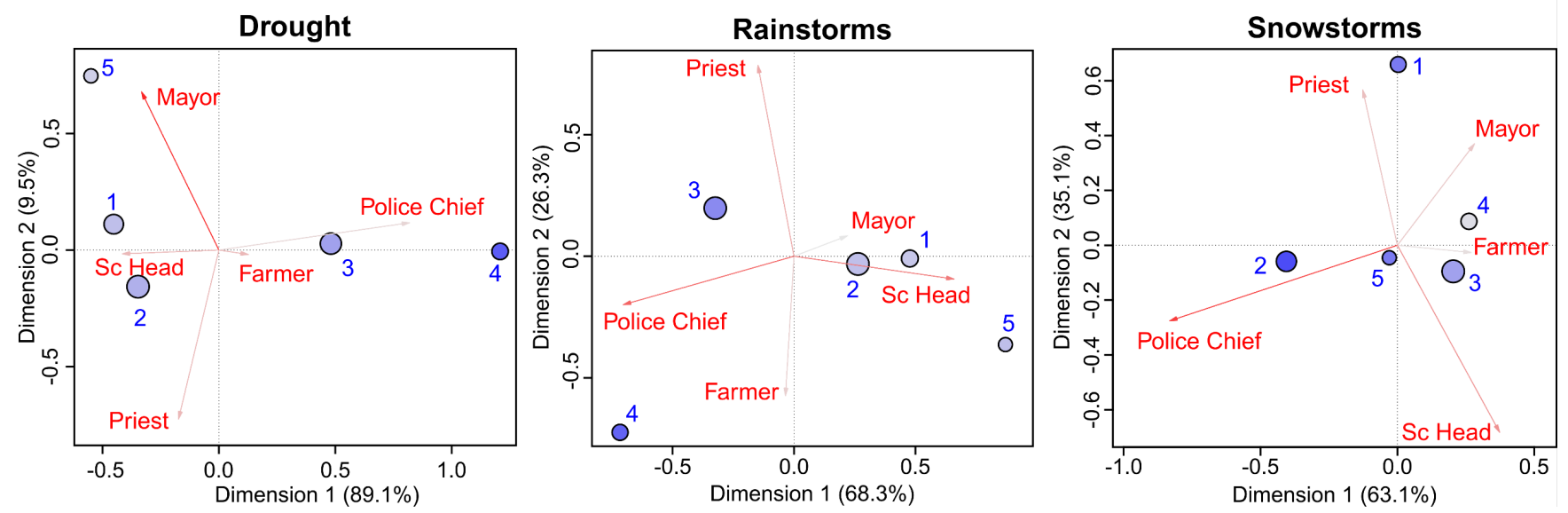

Figure 10: CA contribution biplots for different stakeholders' perceived personal preparedness for droughts, snowstorms, and rainstorms.

The stakeholders' role as leaders of their institution during the events generated by natural hazards is critical. They refer to direct intervention in the affected areas and the management and communication with the entire population of the community. These issues were addressed in the following question. The gathered answers are generally in line with the level of social responsibility of the institutions that stakeholders represent according to the legislation but also to the moral leadership in the community. "high" and "very high" responses were acquired as follows: priests (88\%), police chiefs (86\%), mayors (74\%), school heads (64\%), and farmers (52\%). There are interesting absences of "low" and "very low" responses in the case of mayors, school heads, and priests, and the low proportion of these responses in the case of police chiefs (5\%) and farmers $(7 \%)$.

\section{Discussions and conclusions}

The current study's importance lies in the intrinsic characteristics of Iaşi area, being exposed and vulnerable to major natural hazards and overlapped with recent and historical contradictory socio-economic dynamics of Romania (Ignat et al., 2014). In line with a competitive European economy with increasing educational level and income of the last 20 years, the Romanian society tried to follow the positive trends and numbers, with a rapid urban sprawl. The fast development was characterized by a lack of planning and infrastructural investments leading to an increased vulnerability to natural hazards. At the same time, the dissatisfaction and the feeling of the danger of people were felt even at the political level that, since 1989, has led to a constant decrease of trust in national institutions and their leaders. In this fragile socio-economic and political environment, local stakeholders were involved in national programs to help communities (primarily rural areas) to prevent, manage and recover from emergencies, including weather extremes or natural hazards, because, very often, media, politicians or other public actors demonstrated to discredit these phenomena and their potential negative impact. However, history showed that disaster communication was poorly managed, and local stakeholders lacked in coordinating people in all phases of risk 
management. The lacking knowledge and preparedness understanding of stakeholders pushed the need to investigate their actual perception of natural hazards occurrence to set the scene for improved management at the local level.

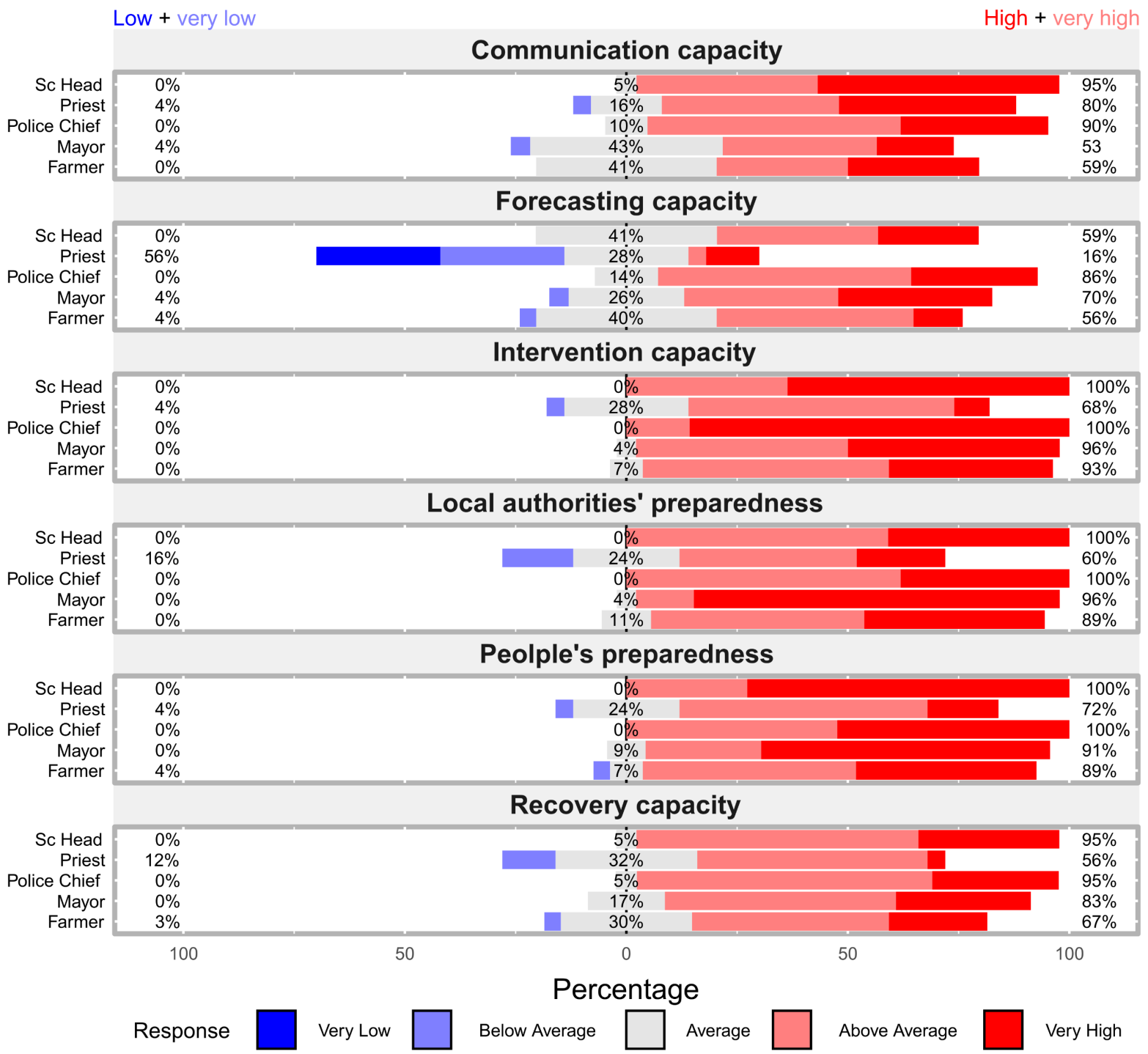

Figure 11: Likert plot of the responses regarding the factors which can increase the actual disaster risk management planning.

540 The results found with 118 interviews in Iaşi Metropolitan Area showed that, in general, there is a moderate level of threat toward the negative influence of climate-related hazards and earthquakes with different levels. The three main themes that are resumed in the questions posed (Q1, Q2, and Q3) reveals differences in risk perception concerning various stakeholders' types and risks, and an obvious specific behavior related to the local geomorphological settings which favor local scale hazards (e.g., landslides and floods). Farmers are more concerned, especially to climate-related hazards, that can directly affect their livelihood and source of income. The literature has found that they might already receive incentives to protect the economic 
sector from the threat of natural hazards and/or invest in insurance products to safeguard household income (Saldaña-Zorrilla, 2008).

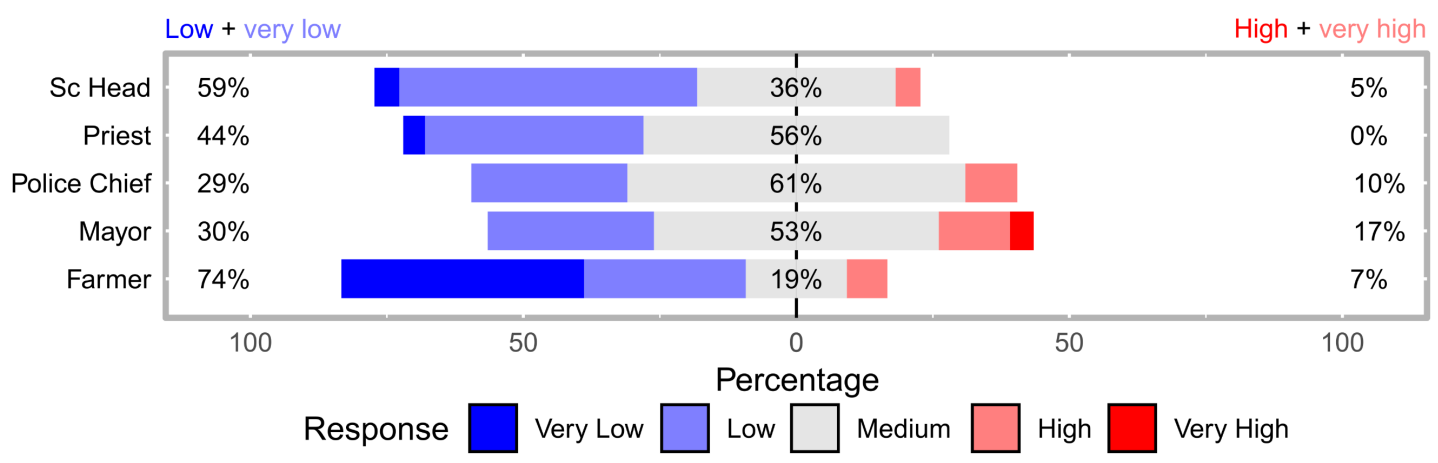

Figure 12: Likert plot of the responses regarding the trust in the actual measures for natural hazards.

Majors, school heads, and priests displayed a greater level of risk awareness on droughts and earthquakes, being on the major and long-lasting events for which planning, evacuation, and recovery is needed to manage the outcome of those events efficiently. Police officers were the only stakeholders recognizing the threat of floods because they were directly involved in recent flooding and rescue activities. Despite recognizing the probability of a wide set of natural hazards, the level of preparedness is perceived to be low. The poor vertical dialogue among stakeholders, the lay public, and higher authorities have scattered communication and proactive behaviors of citizens, rising low levels of trust, and on some occasions, discarding hazard warnings. Stakeholders highlighted great interest in information and education programs to reconstruct their network with the population and reduce the negative effects of natural hazards. The same results have been found in France, where a national concern needs to find solutions and economic investments at the local scale with poor transparency and trust, leading to unmanaged and inefficient solutions and actions (Heitz et al., 2009). Mayors in Iaşi County need to be involved in the discussions and negotiations at the national level, exposing different interests of the community's representativeness and the lay public to promote a horizontal dialogue that gradually would include people in the disaster risk planning. In this regard, stakeholders network needs to be established at the local level, share knowledge, how-how, enhance communication, and rebuild a culture of trust. Networked governance is also highlighted by VanWell et al. (2018) that evidence the virtuous example of the Nordic Centre of Excellence on Resilience and Societal Security network, which includes Denmark, Finland, Iceland, Norway and Sweden and the synergy of communities, institutions, individuals and infrastructures for societal resilience and community development. Simultaneously, the political agenda can help those networks implementing monitoring systems of vulnerable buildings facilitating the knowledge of local stakeholders, their safety, and their relationship with the population moving from a self-centered approach to a community-based approach. Another important issue in disaster risk reduction and management is represented by the involvement of scientists in local committees for emergencies, with specific roles (Gill et al., 2020), such as identification and characterization of potential multi-hazard areas, prioritize effective, positive, long-term partnerships, sharing the experiences of others communities in best practices risk management through improved access to hazard information and embedding cultural understanding into local natural hazard environment. 
The perspectives of this study should be continued in the next years to assess the changes of the behavior of the stakeholders regarding the awareness of the threats posed by natural hazards induced risks in a dynamic perspective, taking into consideration the future events and their negative effects as well as the changes that the citizens will register at the level of increasing (or not) the inter-community cooperation and the compliance with legislation.

\section{Author contribution}

MCM, MN, GR and PT designed the conceptualization, MCM and GR the questionnaire and MCM and MN carried it out. $\mathrm{MN}$ carried the statistical analysis and the plotting. MCM prepared the manuscript with contributions from all co-authors.

\section{Competing interests}

The authors declare that they have no conflict of interest.

\section{Acknowledgements}

MN was supported by a grant of Ministery of Research and Innovation, CNCS - UEFISCDI, project number PN-III-P1-1.1PD-2016-0154, within PNCDI III. The funders had no role in study design, data collection and analysis, decision to publish, or preparation of the manuscript.

\section{References}

Agresti, A.: Categorical Data Analysis, Second Edition. Hoboken, New Jersey, John Wiley\& Sons, 2002.

Agresti, A: Clustered Ordinal Responses: Marginal Models, in: Analysis of Ordinal Categorical Data, Second Edition, John Wiley \& Sons, 262-280, https://doi.org/10.1002/9780470594001.ch9, 2010.

590 Albulescu, A.-C., Larion, D., and Grozavu, A.: Multi-Criteria Assessment of the Seismic Vulnerability of School Units in Vaslui City, Romania, in: Risk Analysis XII, WIT Transactions on Engineering Sciences, edited by: Syngellakis, S. and Fabbri, A., WIT Press, Southampton, UK, 17-28, https://doi.org/10.2495/RISK200021,2020.

Alcántara-Ayala, I. and Moreno, A.R.: Landslide risk perception and communication for disaster risk management in mountain areas of developing countries: a Mexican foretaste, J. Mt. Sci.,13, 2079-2093, https://doi.org/10.1007/s11629-015-3823-0, 5952016.

Alfieri, L., Burek, P., Feyen, L., and Forzieri, G.: Global warming increases the frequency of river floods in Europe, Hydrol. Earth Syst. Sc., 19, 2247-2260, http://doi.org/10.5194/hess-19-2247-2015, 2015.

Alon, I.: COVID-19 and International Business: A Viewpoint, FIIB Business Review, 1-3, https://doi.org/10.1177/2319714520923579, 2020. 
600 Anders, I., Stagl, J., Auer, I., and Pavlik, D.: Climate change in Central and Eastern Europe, in: Managing Protected Areas in Central and Eastern Europe Under Climate Change. Advances in Global Change Research, edited by Rannow, S. and Neubert, M., 58, Springer Science-Business Media Dordrecht, 4, 17-30, https://doi.org/10.1007/978-94-007-7960-0_2, 2014.

Armaş, I.: Earthquake Risk Perception in Bucharest, Romania, Risk Anal, 26, 1223-1234, https://doi.org/10.1111/j.15396924.2006.00810.x, 2006.

605 Armaș, I. and Avram, E.: Perception of flood risk in the Danube Delta, Romania, Nat. Hazards, 50, 269-287, https://doi.org/10.1007/s11069-008-9337-0, 2009.

Armaș, I., Creţu, R.Z., and Ionescu, R.: Self-efficacy, stress, and locus of control: The psychology of earthquake risk perception in Bucharest, Romania, Int. J. Disast. Risk Re., 22, 71-76, https://doi.org/10.1016/j.ijdrr.2017.02.018, 2017.

Armaș, I., Ionescu, R. and Posner, C. N.: Flood risk perception along the Lower Danube river, Romania, Nat. Hazards, 79, 610 1913-1931, https://doi.org/10.1007/s11069-015-1939-8, 2015.

Armstrong, G.D.: Parametric statistics and ordinal data: a pervasive misconception, Nurs. Res., 30, 60-62, https://doi.org/ 10.1097/00006199-198101000-00019, 1981.

Baker, B.O., Hardyck, C.D.and Petrinovich, L.F.: Weak measurements vs. strong statistics: an empirical critique of S.S. Steven's proscriptions on statistics, Educ. Psychol. Meas., 26, 291-309, https://doi.org/10.1177/001316446602600204, 1966.

615 Baker, V.R.: The Story of Vaiont: Told by the Geologist Who Discovered the Landslide, Earth Sciences History, 30, p. 295, 2011.

Banica, A, Rosu, L., Muntele, I. and Grozavu, A.: Towards urban resilience: A multi-criteria analysis of seismic vulnerability in Iasi City (Romania), Sustainability, 9, 270, https://doi.org/10.3390/su9020270, 2017.

Battistini, N. and Stoevsky, G.: Alternative scenarios for the impact of the COVID-19 pandemic on economic activity in the 620 euro area, Economic Bulletin Boxes, European Central Bank, 3, 2020.

Bălteanu, D., Micu, D., Baroiu, D., Dima, V., Dragotă, C., Mărculeţ, C., and Şerban, P.: Snowstorm Spells of January-February 2012: Genesis, Manifestation and Effects in Buzău County Lowland, Apa şi Aerul: Componente ale Mediului, 2013.

Bălteanu, D., Micu, M., Jurchescu, M., Malet, J.-P., Sima, M., Kucsicsa, G., Dumitrică, C., Petrea, D., Mărgărint, M. C., Bilaşco, Ş., Dobrescu, C.-F., Călăraşu, E.-A., Olinic, E., Boţi, I., and Senzaconi, F.: National-scale susceptibility map of 625 Romania in a European methodological framework, Geomorphology, 371, 107432, https://doi.org/10.1016/j.geomorph.2020.107432, 2020.

Benedek, J. and Cristea, M.: Growth pole development and 'metropolization' in post-socialist Romania, Studia UBB Geographia, 59, 125-138, 2014.

Bernardo, F.: Impact of place attachment on risk perception: Exploring the multidimensionality of risk and its magnitude, 630 Studies in Psychology, 34, 323-329, https://doi.org/10.1174/021093913808349253, 2013.

Beshi, T. D. and Kaur, R.: Public Trust in Local Government: Explaining the Role of Good Governance Practices, Public Organization Review, https://doi.org/10.1007/s11115-019-00444-6, 2019. 
Bickerstaff, K. and Walker, G.: Public understanding of air pollution: the "localisation" of environmental risk, Global Environmental Change, 11, 135-145, https://doi.org/10.1016/S0959-3780(00)00063-7, 2001.

635 Bîrsan, M.V.: Variabilitatea regimului natural al râurilor din România [Variability of natural regime of Romanian Rivers], ArsDocendi Press, Bucharest, 100 p., 2017 (in Romanian).

Bunea, G. and Atanasiu, G.M.: Overview of Romania's seismicity focusing on the North-Eastern region, Bul. Inst. Politeh. din Iaşi Sect. Constr. Arhit., 60, 43-52, 2014.

Burja, V.: Some aspects of employment in Romania's agriculture in the European context, Annales Universitatis Apulensis

640 Series Oeconomica, 16, 41-51, 2014.

Busuioc, A., Cuculeanu, V., Tuinea, P., and Geicu, A.: Climate change estimation in Romania by using GCM simulations. Romanian J. of Meteolorolgy, 4, 1-16, 1997.

Busuioc, A., Caian, M., Cheval, S., Bojariu, R., Boroneanț, C., Baciu, M., and Dumitrescu, A.: Variabilitatea și schimbarea climei în România [Variability and climate change in Romania], Pro Universitaria Press, 226 p., 2010 (in Romanian).

645 Busuioc, A., Cuculeanu, V., Tuinea, P., Geicu, A., Simota, C., Marica, A., Alexandrescu, A., Pătrășcoiu, N., Stănescu, A., Șerban, P., Tecuci, I., Simota, M., and Corbuș, C.: Impactul potential al schimbării climei în România [Potential impact of climate change in Romania], ArsDocendi Press, Bucharest University, 230 p., 2013 (in Romanian).

Carifio, J. and Perla, R.J.: Ten Common Misunderstandings, Misconceptions, Persistent Myths and Urban Legends, Journal of Social Sciences, 3, 106-116, http://dx.doi.org/10.3844/jssp.2007.106.116, 2007.

650 Carifio, J. and Perla, R.J.: Resolving the 50-year debate around using and misusing Likert scales, Med. Educ., 42, 1150-1152, HTTPS://DOI.ORG/ 10.1111/j.1365-2923.2008.03172.x, 2008.

Ceobanu, C. and Grozavu, A.: Psychosocial effects of the floods perception and attitudes, Carpath. J. Earth Env., 4, 25-38, 2009.

Chiriac, D., Geicu, A., Humă, C., and Bleahu, A.: Efectele socioeconomice ale secetei asupra calităţii vieţii comunităţiloru mane din România [Socioeconomic effects of droughts on life quality of human communities in Romania], Calitatea Vieţii, 16, 313-331 (in Romanian), 2005.

Cioacă, A. and Dinu, M.: Landslide Reactivation in Moldavian Plateau 1996/1997. A case study: Pârcovaci, Annals of Valahia University of Târgovişte, Geographical series, 2, 136-142, 2002.

Cismaru, C., Bartha, I., Gabor, V., and Scripcariu, D.: Studii asupra deficitului de producţie determinat de secete in condiţiile

Moldovei [Studies on the production deficit caused by droughts in Moldova conditions], Ovidius University Annals of Constructions, 1, 53-57 (in Romanian), 2000.

Cîmpianu, C. and Corodescu, E.: Landscape dynamics analysis in Iaşi Metropolitan Area (Romania) using remote sensing data, Cinq Continents, 3, 18-32, https://nbn-resolving.org/urn:nbn:de:0168-ssoar-359736, 2013.

Comănescu, L. and Nedelea, A.: Public perception of the hazards affecting geomorphological heritage-case study: the central 665 area of Bucegi Mts. (Southern Carpathians, Romania), Environ. Earth Sci., 73, 8487-8497, https://doi.org/10.1007/s12665014-4007-x, 2015. 
Comănescu, L. and Nedelea, A.: Floods and public perception on their effect. Case Study: Tecuci Plain (Romania), year 2013, Procedia Environ. Sci., 32, 190-199, https://doi.org/10.1016/j.proenv.2016.03.024, 2016.

Croitoru, A.-E. and Minea, I.: The impact of climate changes on rivers discharge in Eastern Romania. Theor. Appl.

Climatol.,120, 563-573, https://doi.org/10.1007/s00704-014-1194-z, 2015.

Croitoru, A.-E., Piticar, A., and Burada, D.C.: Changes in precipitation extremes in Romania. Quatern. Int.,415, 325-335, https://doi.org/10.1016/j.quaint.2015.07.028, 2016.

Cuculeanu, V. and Bălteanu, D.: Potential Climate Change Impacts on Water Resources in Romania. Global Change Newsletters, 60, 18-21, 2004.

675 Creţu, R.Z., Armaș, I., and Stănciugelu, I.: Psychological Vulnerability and Earthquake Risk Perception in Bucharest/Romania, EGU General Assembly, 2-7 May, Vienna, Austria, p. 8835, 2010.

Damm, A., Eberhard, K., Sendzimir, J., and Patt, A.: Perception and landslide responsibility: a case study in eastern Styria, Austria, Nat. Hazards, 69, 165-183, https://doi.org/10.1007/s11069-013-0694-y, 2013.

Deryugina, T.: How do people update? The effects of local weather fluctuations on beliefs about global warming, Climatic

Change, 118, 397-416, https://doi.org/10.1007/s10584-012-0615-1, 2013.

Dicu, I. and Stângă, I. C.: Exposure and Triggering Factors of Road (Un-) Safety and Risks in Iaşi Municipality (Romania), Scientific Annals of "Alexandru Ioan Cuza" University of Iaşi, 59, s. II c, Geography series, 171-190, 2013.

Donat, M.G., Lowry, A.L., Alexander, L.V., O'Gorman, P.A., and Maher, N.: More extreme precipitation in the world's dry and wet regions, Nat. Clim. Change, 6, 508-513, https://doi.org/10.1038/nclimate2941, 2016.

685 Donat, M.G., Lowry, A.L., Alexander, L.V., O’Gorman, P.A., and Maher, N.: Addendum: More extreme precipitation in the world's dry and wet regions,Nat.Clim. Change, 6, 508-513, https://doi.org/10.1038/nclimate3160, 2017.

Dottori, F., Szewczyk, W., Ciscar, J., Zhao, F., Alfieri, L., Hirabayashi, Y., Bianchi, A., Mongelli, I., Frieler, K., Betts, A., and Feyen, L.: Increased human and economic losses from river flooding with anthropogenic warming, Nat. Clim. Change., 8, 781-786, https://doi.org/10.1038/s41558-018-0257-z, 2018.

690 Dunford, R., Harrison, P.A., Jäger, J., Rounsevell, M.D.A., and Tinch, R.: Exploring climate change vulnerability across sectors and scenarios using indicators of impacts and coping capacity, Climatic Change,128, 339-354, https://doi.org/10.1007/s10584-014-1162-8, 2015.

Dutu, A, Niste, M., Spatarelu, I., Dima, D. I., and Kishiki, S.: Seismic evaluation of Romanian traditional buildings with timber frame and mud masonry infills by in-plane static cycling tests, Eng. Struct., 167, 655-670, 695 https://doi.org/10.1016/j.engstruct.2018.02.062, 2018.

Dykes, A.P. and Bromhead, E.N. The Vajont landslide: re-assessemnt of the evidence leads to rejection of the consensus, Landslides, 15, 1815-1832, https://doi.org/10.1007/s10346-018-0996-y, 2018.

Egan, P.J. and Mullin, M.: Turning personal experience into political attitudes: the effect of local weather on Americans' perceptions about global warming, J. Politics, 74, 796-809. https://doi.org/10.1017/s0022381612000448, 2012. 
Emergency Response Coordination Centre (ERCC). Romania - Disaster management structure, https://erccportal.jrc.ec.europa.eu/vademecum/ro/2-ro-1.html (last access:12October2020).

Formetta, G. and Feyen, L.: Empirical evidence of declining global vulnerability to climate-related hazards. Global Environ. Chang., 57, 1-9, 101920, https://doi.org/10.1016/j.gloenvcha.2019.05.004, 2019.

Forzieri, G., Feyen, L., Rojas, R., Flörke, M., Wimmer, F., and Bianchi, A.: Ensemble projections of future streamflow droughts in Europe, Hydrol. Earth Syst. Sc., 18, 85-108. http://doi.org/10.5194/hess-18-85-2014, 2014.

Forzieri, G., Bianchi, A., Silva, F.B.E., Marin Herrera, M.A., Leblois, A., Lavalle, C., Aerts, J.C.J.H., and Feyen, L.: Escalating impacts of climate extremes on critical infrastructures in Europe, Global Environ. Chang. Part A.,48, 97-107. https://doi.org/10.1016/j.gloenvcha.2017.11.007, 2018.

Fuchs, S., Karagiorgos, K., Kitikidou, K., Maris, F., Paparrizos, S., and Thaler, T.: Flood risk perception and adaptation capacity: a contribution to the socio-hydrology debate,Hydrol. Earth Syst. Sc., 21, 3183-3198, https://doi.org/10.5194/hess21-3183-2017, 2017.

Gaito, J.: Measurement scales and statistics: resurgence of an old misconception, Psychol. Bull., 87, 564-567, https://doi.org/10.1037/0033-2909.87.3.564,1980.

Gao, X., Roder, G., Jiao, Y., Ding, Y., Liu, Z., and Tarolli, P.: Farmers' landslide risk perceptions and willingness for

715 restoration and conservation of world heritage site of Honghe Hani Rice Terraces, China, Landslides, 17, 1915-1924, https://doi.org/10.1007/s10346-020-01389-4, 2020.

Gardner, H.J. and Martin, M.A.: Analyzing Ordinal Scales in Studies of Virtual Environments: Likert or Lump It! PresenceTeleop. Virt., 16, 439-446, https://doi.org/10.1162/pres.16.4.439, 2007.

Georgescu, E.-S. and Pomonis, A: The Romanian Earthquake of March 4, 1977 Revisited: New Insights into its Territorial,

720 Economic and Social Impacts and their Bearing on the Preparedness for the Future, the 14th World Conference on Earthquake Engineering, October 12-17, 2008, Beijing, China, 2008.

Georgescu, F., Tascu, S., Caian, M., and Banciu, D.: A severe blizzard event in Romania - a case study, Nat. Hazards Earth Syst. Sci., 9, 623-634, https://doi.org/10.5194/nhess-9-623-2009, 2009.

Gill, J. C., Taylor, F. E., Duncan, M. J., Mohadjer, S., Budimir, M., Mdala, H., and Bukachi, V.: Invited perspectives: Building 725 sustainable and resilient communities - recommended actions for natural hazard scientists, Nat. Hazards Earth Syst. Sci., 21, 187-202, https://doi.org/10.5194/nhess-21-187-2021, 2021.

Greenacre, M.: Correspondence Analysis in Practice. Second Edition. London: Chapman\& Hall / CRC, 2007.

Greenacre, M.: Contribution Biplots, J. Comput. Graph. Stat., 22, 107-122, https://doi.org/10.1080/10618600.2012.702494,2013.

730 Grozavu, A. and Pleşcan, S.: The Natural Risk Perception in Lepşa-Greşu Depression, Present Environment and Sustainable Development, 4, 199-210, 2010.

Gruber, S.: The impact of climate change on cultural heritage sites: environmental law and adaptation, Carbon Clim. Law Rev.5, 209-219, 2011. 
Haylock, M.R., Hofstra, N., Klein Tank, A.M.G., Klok, E.J., Jones, P.D., and New, M.: European daily high-resolution gridded dataset of surface temperature and precipitation. J. Geophys. Res.-Atmos., 113, D20119, https://doi.org/10.1029/2008JD10201, 2008.

Hazarika, N., Tayeng, T., and Das, A.K.: Living in troubled waters: stakeholders' perception, susceptibility and adaptations to flooding in the Upper Brahmaputra plain. Nat. Hazards, 83, 1157-1176. https://doi.org/10.1007/s11069-016-2366-1, 2016. Heitz, C., Spaeter, S., Auzet, A.V., and Glatron, S.: Local stakeholders' perception of muddy flood risk and implications for management approaches: A case study in Alsace (France). Land Use Policy, 26, 443-451, https://doi.org/10.1016/j.landusepol.2008.05.008, 2009.

Hommels, A. and Cleophas, E.: In Case of Breakdown: Dreams and Dilemmas of a Common European Standard for Emergency Communication, in: The Making of Europe's Critical Infrastructure. Common Connections and Shared Vulnerabilities, edited by: Högselius, P., Hommels, A., Kaijser, A., and van der Vleuten, E., Palgrave MacMillan, London, 239-260, https://doi.org/10.1057/9781137358738_9, 2013.

Horton, R.M., Gornitz, V., Bader, D.A., Ruane, A.C., Goldberg, R., and Rosenzweig, C.: Climate Hazard Assessment for Stakeholder Adaptation Planning in New York City, J. App. Met. Climatol., 50, 2247-2266, https://doi.org/10.1175/2011JAMC2521.1, 2011.

Hothorn, T., Hornik, K., van de Wiel, M. A., and Zeileis. A.: Implementing a Class of Permutation Tests: The coin Package, Journal of Statistical Software, 28, 1-23, http://www.jstatsoft.org/v28/i08/, 2008.

Iaţu, C. and Eva, M.: Spatial profile of the evolution of urban sprawl pressure on the surroundings of Romanian cities (20002013), Carpath. J. Earth Env., 11, 79-88, 2016.

Iftimoaei, C. and Baciu, I.C.: Populaţia din Zona Metropolitană Iaşi: volum, structure şi procesedemografice [Population of the Iaşi Metropolitan Area. Volume, Structures and Demographic Processes], in: Dezvoltarea Economico-Socială a Euroregiunilor şi a Zonelor Transfrontaliere, edited by: Păduraru, T. et. al., 33, Edit. Performantica, Iaşi, 313-328, 2018.

Ignat, R., Stoian, M. and Roşca, V.: Socio-economic Aspects of Rural Romania, Procedia Economics and Finance, 15, 13311338, https://doi.org/10.1016/S2212-5671(14)00596-6, 2014.

Ingram, W.: Increases all round, Nat. Clim. Change, 6, 443-444. https://doi.org/10.1038/nclimate2966., 2016. Intergovernmental Panel on Climate Change (IPCC). Climate Change 2013: The Physical Science Basis. Contribution of

760 Working Group I to the Fifth Assessment Report of the Intergovernmental Panel on Climate Change. in: Climate Change 2013. The Physical Science Basis, edited by: Stocker, T.F., Qin, D., Plattner, G.-K., Tignor, M. M. B., Allen, S.K., Boschung, J., Nauels, A., Xia, Y., Bex, V., and Midgley, P.M., Cambridge University Press, Cambridge, United Kingdom and New York, NY, USA, https://doi.org/10.1017/CBO9781107415324.004, 2013.

Intergovernmental Panel on Climate Change (IPCC) (2018) Global Warming of $1.5^{\circ} \mathrm{C}$. An IPCC Special Report on the impacts 765 of global warming of $1.5^{\circ} \mathrm{C}$ above pre-industrial levels and related global greenhouse gas emission pathways, in the context of strengthening the global response to the threat of climate change, sustainable development, and efforts to eradicate poverty, Masson-Delmotte, V., Zhai, P., Portner, H.-O., Roberts, D., Skea, J., Shukla, P.R., Pirani, A..Moufouma-Okia, W., Pean, C., 
Pidcock, R., Connors, S., Matthews, J.B.R., Chen, Y., Zhou, X., Gomis, M.I., Lonnoy, E., Maycock, T., Tignor, M., and Waterfield, T. (Eds.), IPCC, Geneva, Switzerland, 562 p., 2018. G., Georgopoulou, E., Gobiet, A., Menut, L., Nikulin, G., Haensler, A., Hempelmann, N., Jones, C., Keuler, K., Kovats, S., Kröner, N., Kotlarski,S., Kriegsmann, A., Martin, E., van Meijgaard, E., Moseley, C., Pfeifer, S., Preuschmann, S., Radermacher, C., Radtke, K., Rechid, D., Rounsevell, M., Samuelsson, P., Somot, S., Soussana,J.-F., Teichmann, C., Valentini, R., Vautard, R., Weber, B., and Yiou, P.: EURO-CORDEX: new high resolution climate change projections for European impact research. Reg. Environ. Change, 14, 563-578, https://doi.org/10.1007/s10113-013-0499-2, 2014.

Jamieson, S.: Likert scales: how to (ab)use them, Med. Educ., 38(12), 1217-1218, https://doi.org/10.1111/j.13652929.2004.02012.x, 2004.

Jurchescu, M., Micu, D., Sima, M., Bălteanu, D., Dragotă, C., Micu, M., Bojariu, R.and Dumitrescu, A.: An approach to investigate the effects of climate change on landslide hazard at a national scale (Romania), in: Proceedings of Romanian

Geomorphology Symposium, edited by: Niculiță, M. and Mărgărint, M.C., 1, Iași,11-14 May 2017, Alexandru Ioan Cuza University of Iași Press, 121-124, https://doi.org/10.15551/prgs.2017.121, 2017.

Kaplan, H., Bilgin, H., Yilmaz, S., Binici, H., and Öztaz, A.: Structural damages of L'Aquila (Italy) earthquake, Nat. Hazards Earth Syst. Sci., 10, 499-507, https://doi.org/10.5194/nhess-10-499-2010, 2010.

Kero, P. and Lee, D.: Likert is Pronounced "LICK-urt" not "LIE-kurt" and the Data are Ordinal not Interval, J. Appl. Meas., 17, 502-509, 2016.

Knapp, T.R.: Treating ordinal scales as interval scales: An attempt to resolve the controversy, Nurs. Res., 39, 121-123, 1990. Knuth, D., Kehl, D., Hulse, L., Spangenberg, L., Brähler, E., and Schmidt, S.: Risk perception and emergency experience: comparing a representative German sample with German emergency survivors, J. Risk Res., 18, 581-601. https://doi.org/10.1080/13669877.2014.910685, 2015.

Kottek, M., Grieser, J., Beck, C., Rudolf, B., and Rubel, F.: World Map of the Köppen-Geiger climate classification updated, Meteorologische Zeitschrift, 15, 259-263. http://doi.org/10.1127/0941-2948/2006/0130, 2006.

Kraaij-Dirkzwager, M., van der Ree, J., and Lebret, E.: Rapid Assessment of Stakeholder Concerns about Public Health. An Introduction to a Fast and Inexpensive Approach Applied on Health Concerns about Intensive Animal Production Systems, Int. J. Environ. Res. Public. Health., 14, 1534, http://doi.org/10.3390/ijerph14121534., 2017.

Kron, W.: Natural Disasters: Lessons from the Past - Concerns for the Future, Geneva Pap. Risk Insur. Issues Pract., Vol. 25, No. 4, 570-581, https://doi.org/10.1111/1468-0440.00083, 2000.

Kurnik, B., Füssel, H.M., van der Linden, P., Simmons, A., Hildén, M., and Fronzek, S.: Changes in the climate system. in: Climate change, impacts and vulnerability in Europe 2016. An indicator-based report, European Environment Agency Report, 1, 61-104, http://doi.org/10.2800/534806, 2017.

800 Li, Y., Johnson, E.J., and Zaval, L.: Local warming: daily temperature change influences belief in global warming, Psychol. Sci.,22, 454-459,https://doi.org/10.1177/0956797611400913, 2011. 
Lungu, D., Ariton C., Aldea, A., and Vacareanu, R.: Seismic Hazard, Vulnerability and Risk for Vrancea Events, International Symposium on strong Vrancea Earthquakes and Risk Mitigation, 4-6 October, 2007, Bucharest, Romania, 291-306, 2007. Mainardes, E.W., Alves, H., and Raposo, M.: A model for stakeholder classification and stakeholder relationships, Manage.

Decis.,50, 1861-1879, https://doi.org/10.1108/00251741211279648, 2012.

Mangiafico, S.S.: Summary and Analysis of Extension Program Evaluation in R, version 1.15.0., Rutgers Cooperative Extension, New Brunswick, NJ. http://rcompanion.org/documents/RHandbookProgramEvaluation.pdf, last accessed: 28 October 2020, 2016.

Mărgărint, M.C. and Niculiță, M.: Local stakeholders' perception of natural risks. Case study of Iaşi County, NE Romania, in:

Proceedings of International conference Analysis and Management of Changing Risks for Natural Hazards, 18-19 November 2014, Padova, Italy, 10p, 2014.

Mărgărint, M.C. and Niculiţă, M.: Using high resolution LIDAR DEM to reconstruct historical network of lakes and wetlands in the Northern part of the Moldavian Plateau, NE Romania, Georeview, 26, p. 59, 2016.

Mărgărint, M.C. and Niculiţă, M.: Landslide type and pattern in Moldavian Plateau, NE Romania, in: Landform Dynamics

815 and Evolution in Romania, edited by: Rădoane, M. and Vespremeanu-Stroe, A. Springer Geography, Springer, Cham, 271304, http://doi.org/10.1007/978-3-319-32589-7_12, 2017.

Mărmureanu, G., Cioflan, C. O. and Mărmureanu, A.: Intensity Seismic Hazard Map of Romania by Probabilistic and (Neo)Deterministic Approaches, Linear and Nonlinear Analyses, Rom. Rep. Phys., 63, 336-239, 2011.

McCoy, S.J. and Walsh, R.P.: Wildfire, salience \& housing demand, J. of Environ. Econ. and Manag., 91, 203-228, https://doi.org/10.1016/j.jeem.2018.07.005, 2018.

Meltzer, M., Ștefănescu, L., and Ozunu, A.: Keep Them Engaged: Romanian County Inspectorates for Emergency Situations’ Facebook Usage for Disaster Risk Communication and Beyond, Sustainability, 10, 1411, https://doi.org/10.3390/su10051411, 2018.

Merz, B., Hall, J., Disse, M., and Schumann, A.: Fluvial flood risk management in a changing world, Nat. Hazards Earth Syst.

Sci., 10, 509-527, https://doi.org/10.5194/nhess-10-509-2010, 2010.

Micu, M., Jurchescu, M., Șandric, I., Mărgărint, M. C., Chiţu, Z., Micu, D., Ciurean, R., Ilinca, V., Vasile, M., Mass Movements, in: Landform Dynamics and Evolution in Romania, edited by: Rădoane, M. and Vespremeanu-Stroe, A. Springer Geography, Springer, Cham, 765-820, https://doi.org/10.1007/978-3-319-32589-7_32, 2017, 2017.

Mihăilă, D.: Câmpia Moldovei: studiu climatic [Moldavian Plain: climatic study], Suceava University Press, 465 p. (in 830 Romanian), 2006.

Minea, I.: Bazinul hidrografic Bahlui. Studiu hidrologic [Bahlui catchment. Hydrological study]. Alexandru Ioan Cuza University of Iași Press, Iași, 334 p. (in Romanian), 2013.

Minea, I. and Croitoru, A.-D.: Climate changes and their impact on the variation of the groundwater level in the Moldavian Plateau (Eastern Romania),15th International Multidisciplinary Scientific GeoConference (SGEM2015),137-144, 
Minea, I., Hapciuc, O.-E., Bănuc, G., and Jora, I.: Trends and variations of the groundwater level in the North-eastern part of Romania,16th International Multidisciplinary Scientific GeoConference (SGEM2016), 1053-1060, https://doi.org/10.5593/SGEM2016/B11/S02.133, 2016.

Ministerul Educației Naționale și Cercetării Științifice: Regulamentul-cadru de organizare și funcționare a unităților de învățământ preuniversitar, Managementul unităţilor de învăţământ - Cap. 3 Directorul, Monitorul Oficial, 720, 1, https://lege5.ro/Gratuit/gezdqmzygyya/directorul-regulament?dp=geydimjzha3tcny, 19 September 2016. (in Romanian)

Mircioiu, C. and Atkinson, J.A.: Comparison of Parametric and Non-Parametric Methods Applied to a Likert Scale. Pharmacy (Basel), 5, 26, https://doi.org/10.3390/pharmacy5020026, 2017.

Mitchell, R.K., Agle, B.R., and Wood, D.J.: Toward a Theory of Stakeholder Identification and Salience: defining the Principle 845 of who and What Really Counts. The Academy of Management Review,22, 853-886, http://www.jstor.org/stable/259247, 1997.

Mondino, E., Di Baldassarre, G., Mård, J., Ridolfi, E., Rusca, M.: Public perceptions of multiple risks during the COVID-19 pandemic in Italy and Sweden. Sci Data 7, 434, https://doi.org/10.1038/s41597-020-00778-7, 2020.

Mosoarca, M. and Gioncu, V.: Failure mechanisms for historical religious buildings in Romania seismic areas, J. Cult. Herit., 850 14, e65-e72, https://doi.org/10.1016/j.culher.2012.11.018, 2013.

Moss, R.H., Edmonds, J.A., Hibbard, K.A., Manning, M.R., Rose, S.K., van Vuuren, D.P., Carter, T.R., Emori, S., Kainuma, M., Kram, T., Meehl, G.A., Mitchell, J.F.B., Nakicenovic, N., Riahi, K., Smith, S.J., Stouffer, R.J., Thomson, A.M., Weyant, J.P., and Wilbanks, T.J.: The next generation of scenarios for climate change research and assessment, Nature, 463, 747-756. https://doi.org/10.1038/nature08823, 2010.

855 National Organization System: Emergency Ordinance 20/2004 on National Management System of Emergency Situation, https://lege5.ro/Gratuit/gu3dgmby/organizarea-sistemului-national-ordonanta-de-urgenta-21-2004?dp=gi2taojugm3dc, last accessed 04 October 2020, 2004.

Nenadic, O. and Greenacre, M.: Correspondence Analysis in R, with Two- and Three-dimensional Graphics: The ca Package, Journal of Statistical Software, 20, http://www.jstatsoft.org/v20/i03/, 2007.

860 Niacşu, L., Sfîcă, L., Ursu, A., Ichim, P., Bobric, D.E., and Breabăn, I.G.: Wind erosion on arable lands, associated with extreme blizzard conditions within the hilly area of Eastern Romania, Environ. Res., 169, 86-101, https://doi.org/10.1016/j.envres.2018.11.008, 2019.

Niculiţă, M.: Landslide Hazard Induced by Climate Changes in North-Eastern Romania, in: Climate Change, Hazards and Adaptation Options. Climate Change Management, edited by: Leal Filho, W., Nagy, G., Borga, M., Chávez Muñoz, P., and 865 Magnuszewski, A., Springer, Cham, 245-265, https://doi.org/10.1007/978-3-030-37425-9_13, 2020.

Niculiță, M., Andrei, A., and Lupu, C.: The landslide database of the North-Eastern Romania, in: Proceedings of Romanian Geomorphology Symposium,edited by: Niculiță, M. and Mărgărint, M.C., 1, Iași,11-14 May 2017, AlexandruIoanCuza University of Iaşi Press, Iași, 81-84. http://doi.org/10.15551/prgs.2017.81, 2017. 
Niculiță, M., Stoilov-Linu, V., and Necula, N.: Recent landslides from Iaşi Metropolitan Area, Revista de Geomorfologie, 20,

90-101, http://doi.org/10.21094/rg.2018.030, 2018.

Niculiţă, M., Mărgărint, M.C., and Cristea, A.I.: Using archaeological and geomorphological evidence for the establishment of a relative chronology and evolution pattern for Holocene landslides, PLoS ONE, 14, e0227335, https://doi.org/10.1371/journal.pone.0227335, 2019.

Norman, G.: Likert scales, levels of measurement and the „,laws ${ }^{\text {eeee }}$ Adv. Health Sci. Educ., 15, 625-632, https://doi.org/10.1007/s10459-010-9222-y, 2010.

Oliver, C.E.: Catastrophic Disaster Planning and Response, 1st Edition, CRC Press, 401 p., 2010.

Oppenheim, A.N.: Questionnaire Design, Interviewing and Attitude Measurement, Bloomsbury Academic, 312 p., 2000.

Öhman, S.: Previous Experiences and Risk Perception: The Role of Transference, Journal of Education, Society and Behavioural Science, 23, 1-10, https://doi.org/10.9734/JESBS/2017/35101, 2017.

880 Pelin, L.I.: Fenomenul de secetă din Câmpia Moldovei [Drought in Moldavian Plain]. PhD thesis, Alexandru Ioan Cuza University of Iași, 154 p. (in Romanian), 2015.

Pell, G. Use and misuse of Likert scales, Med. Educ., 2005, 39, 970, https://doi.org/ 10.1111/j.1365-2929.2005.02237.x, 2005.

Pereira, P., Mierauskas, P., and Novara, A.: Stakeholders perception about fire impact in Lithuanian protected areas, Land Degrad. Dev., 27, 871-883, https://doi.org/10.1002/ldr.2290, 2016.

885 Prăvălie, R., Patriche, C., Săvulescu, I., Sîrodoev, I., Bandoc, G., and Sfîcă, L.: Spatial assessment of land sensitivity to degradation across Romania. A quantitative approach based on the modified MEDALUS methodology, Catena, 187, 104407, https://doi.org/10.1016/j.catena.2019.104407, 2020.

Pujină, D.: Alunecările de teren din PodişulMoldovei [Landslides from the Moldavian Plateau]. Edit. Performantica, Iaşi (in Romanian), 2008.

890 Quinn, T., Bousquet, F., Guerbois, C., Sougrati, E., and Tabutaud, M.: The dynamic relationship between sense of place and risk perception in landscapes of mobility, Ecol. Soc. 23, 39, https://www.ecologyandsociety.org/vol23/iss2/art39/,2018.

R Core Team.: R: A language and environment for statistical computing. R Foundation for Statistical Computing, Vienna, Austria, https://www.R-project.org/, 2020.

Reed, M. S.: Stakeholder participation for environmental management: A literature review, Biol. Conserv., 141, 2417-2461, 895 https://doi.org/10.1016/j.biocon.2008.07.014, 2008.

Reker, J., Christiansen, T., Füssel, H.-M., Vaughan, D., Meakins, B., Meiner, A., Palmer, M., Skovgaard Madsen, K., Vanneuville, W., Kristensen, P., Kurnik, B., Feyen, L., Marx, A., Bastrup-Birk, A., Louwagie, G., Wugt-Larsen, F., Biala, K., Schweiger, O., Settele, J., Civic, K., Delbaere, B., Borrelli, P., Jones, A., Lugato, E., Panagos, P., Barredo, J., and Erhard, M.:Climate change impacts on environmental systems, in: Climate change, impacts and vulnerability in Europe 2016. An 900 indicator-based report,European Environment Agency Report 1, 105-188,http://doi.org/10.2800/534806., 2017.

Renn, O.: The role of risk perception for risk management, Reliab. Eng. Syst. Safe, 59, 49-62, https://doi.org/10.1016/S09518320(97)00119-1, 1998. 
Reser, J.P., Bradley, G.L., Glendon, A.I., Ellul, M., and Callaghan, R.: Public risk perceptions, understandings and responses to climate change in Australia and Great Britain, National Climate Change Adaptation Research Facility, Gold Coast, 298 p., 2012.

Reser, J.P., Bradley, G.L., and Ellul, M.C.: Encountering climate change: 'seeing' is more than 'believing', Wiley Interdiscip. Rev. Clim. Change, 5, 521-537, https://doi.org/10.1002/wcc.286, 2014.

Reynolds, T.W., Bostrom, A., Read, D., and Morgan, M.G.: Now what do people know about global climate change? Survey studies of educated laypeople, Risk Anal.,30, 1520-1538, https://doi.org/10.1111/j.1539-6924.2010.01448.x, 2010.

910 Roder, G., Ruljigaljig, T., Lin, C.W., and Tarolli, P.: Natural hazards knowledge and risk perception of Wujie indigenous community in Taiwan,Nat. Hazards, 81, 641-662,https://doi.org/10.1007/s11069-015-2100-4, 2016.

Romanescu, G., Jora, I., and Stoleriu, C.: The most important high floods in Vaslui river basin - causes and consequences, Carpath J. Earth Env. Sci., 6, 119-132., 2011a.

Romanescu, G., Stoleriu, C., Romanescu, A.M.: Water reservoirs and the risk of accidental flood occurrence. Case study:

915 Stânca-Costești reservoir and the historical floods of the Prut river in the period July-August 2008, Romania, Hydrol. Process., 25, 2056-2070. https://doi.org/10.1002/hyp.7957, 2011 b.

Romanescu, G.: Floods characteristics to the Prut river (Romania), Riscuri şi catastrofe, 16, 73-86, 2015.

Romanescu, G., Cimpianu, C. I., Mihu-Pintilie, A., and Stoleriu, C. C.: Historic floods events in NE Romania (post-1990), J. Maps, 13, 787-798, https://doi.org/10.1080/17445647.2017.1383944, 2017.

920 Romanian Government, Emergency Ordinance 68/2020 for modification and completion of legislation regarding emergency situation management and civil protection, http://legislatie.just.ro/Public/DetaliiDocumentAfis/225585, last accessed: 09January 2021.

Romanian Government: Codul administrativ - Atribuţiile primarului, Monitorul Oficial, 555, 1, https://lege5.ro/Gratuit/gm2dcnrygm3q/atributiile-primarului-codul-administrativ?dp=gi4tcojwha4teoi， 5 July 2019. (in

Romanian)

Romanian Government: Statutul pentru organizarea și funcționarea Bisericii Ortodoxe Române, Monitorul Oficial, 97, 1, https://lege5.ro/Gratuit/gezdamrrge/statutul-pentru-organizarea-si-functionarea-bisericii-ortodoxe-romane-din-16012008, 10 February 2020. (in Romanian)

Romanian Parlament: Legea nr. 218 din 23 aprilie 2002 (*republicată*), privind organizarea şi funcţionarea Poliţiei Române, Monitorul Oficial, 170, http://legislatie.just.ro/Public/DetaliiDocument/35841, 2 March 2020. (in Romanian)

Rotaru, A. and Răileanu, P.: Alunecarea de teren de la Pârcovaci, Judeţul Iaşi [Pârcovaci landslide, Iaşi County], International PIARC Seminar on "Managing Operational Risk on Roads" Iaşi, Romania 5-7 November 2009, 1-6, 2009 (in Romanian). Saldaña-Zorrilla, S.O.: Stakeholders' views in reducing rural vulnerability to natural disasters in Southern Mexico: Hazard exposure and coping and adaptive capacity, Global Environ. Chang., 18, 583-597, 935 https://doi.org/10.1016/j.gloenvcha.2008.09.004, 2008. 
Salvati, P., Bianchi, C., Fiorucci, F., Giostrella, P., Marchesini, I., and Guzzetti, F.: Perception of flood and landslide risk in Italy: a preliminary analysis, Nat. Hazards Earth Syst. Sci.,14, 2589-2603, https://doi.org/10.5194/nhess-14-2589-2014, 2014. Scheer, D., Benighaus, C., Benighaus, L., Renn, O., Gold, S., Röder, B., and Böl, G.-F.: The Distinction Between Risk and Hazard: Understanding and Use in Stakeholder Communication, Risk Anal., 34, 1270-1285, http://doi.org/10.1111/risa.12169, 2014.

Scheuer, S. and Haase, D.: Operationalizing expert knowledge and stakeholder preferences in integrated natural hazard risk assessment, Int. Congress on Environmental Modelling and Software, 6, https://scholarsarchive.byu.edu/iemssconference/2012/Stream-B/6, last accessed: 12 October 2020, 2012.

Scolobig, A.: Stakeholder perspectives on barriers to landslide risk governance, Nat. Hazards, 81 (Suppl 1), 27-43, 945 https://doi.org/10.1007/s11069-015-1787-6, 2016.

Slovic, P.: Perception of Risk, Science, 236, 280-285, https://doi.org/10.1126/science.3563507, 1987.

Slovic, P.: Perceived risk, trust, and democracy, Risk Anal., 13, 675-682, https://doi.org/10.1111/j.15396924.1993.tb01329.x,1993.

Slovic, P., Fischhoff, B., and Lichtenstein, S.: Why Study Risk Perception? Risk Anal. 2, 83-93. https://doi.org/10.1111/j.1539-6924.1982.tb01369.x, 1982.

Sparrevik, M., Ellen, G.J., and Duijn, M.: Evaluation of Factors Affecting Stakeholder Risk Perception of Contaminated Sediment Disposal in Oslo Harbor, Environ Sci. Technol.,45, 118-124, https://doi.org/10.1021/es100444t, 2011.

Spinoni, J., Naumann, G., Voght, J.V., and Barbosa, P.: The biggest drought events in Europe from 1950 to 2012, Journal of Hydrology: Regional Studies,3, 509-524, https://doi.org/10.1016/j.ejrh.2015.01.001, 2015.

955 Stagge, J.H., Rizzi, J., Tallaksen, L.M., and Stahl, K.: Future meteorological drought: Projections of regional climate models for Europe, Drought R\&SPI Technical Report No 25, Oslo, 19 p., 2015.

Stahl, K., Tallaksen, L.M., Hannaford, J., and van Lanen, H.A.J.: Filling the white space on maps of European runoff trends: estimates from a multi-model ensemble, Hydrol. Earth Syst. Sc.,16, 2035-2047, http://doi.org/10.5194/hess-16-2035-2012, 2012.

960 Sterling, E. J., Betley, E., Sigouin, A., Gomez, A., Toomey, A., Cullman, G., Malone, C., Pekor, A., Arengo, F., Blair, M., Filardi, C., Landrigan, K., and Porzecanski, A. L: Assessing the evidence for staleholder engagement in biodiversity conservation, Biol. Conserv., 209, 159-171, https://doi.org/10.1016/j.biocon.2017.02.008, 2017.

Stevens, S.S.: Measurement, statistics and the schemapiric view, Science, 161, https://doi.org/10.1126/science.161.3844.849, 849-856, 1968.

965 Stoleriu, O.-M.: Evoluţia uman-geografică şi urbanistică a oraşului Iaşi în perioada postbelică [Human-geographic and urbanistic evolution of Iaşi city in the postbelic period], Edit. Terra Nostra, Iaşi (in Romanian), 2008.

Straja, S. R., Love, B., R, and Moghissi, A. A.: Assessment of stakeholders' trust in governmental decisions-making regarding environmental problems, International Journal of Environment and Health, 2., 239-357, http://doi.org/10.1504/IJENVH.2008.020667, 2008. 
Strand, L.B., Tong, S., Aird, R., and McRae, D.: Vulnerability of eco-environmental health to climate change: the views of government stakeholders and other specialists in Queensland, Australia, BMC Public Health, 10, 441, http://doi.org/10.1186/1471-2458-10-441, 2010.

Šūmane, S., Kunda, I., Knickel, K., Strauss, A., Tisenkopfs, T., des los Rios, I., Rivera, M., Chebach, T., and Ashkenazy, A.: Local and farmers' knowledge matters! How integrating informal and formal knowledge enhances sustainable and resilient agriculture, J. Rural Stud., 59, 232-241, https://doi.org/10.1016/j.jrurstud.2017.01.020, 2018.

Taylor, S.E. and Thompson, S.C.: Stalking the elusive "vividness" effect, Psychol. Rev.,89, 155-181, https://doi.org/10.1037/0033-295X.89.2.155, 1982.

Taylor, A., Bruine de Bruin, W. and Dessai, S.: Climate change beliefs and perceptions of weather-related changes in the United Kingdom, Risk Anal., 34, 1995-2004, https://doi.org/10.1111/risa.12234, 2014a.

980 Taylor, A., Dessai, S., and Bruinede Bruin, W.: Public perception of climate risk and adaptation in the UK: A review of the literature,Climate Risk Management, 4-5, 1-16,https://doi.org/10.1016/j.crm.2014.09.001, 2014b.

Thaler, T., Attems, M.-S., Bonnefond, M., Clarcke, D., Gatien-Tournat, A., Gralepois, M., Fournier, M., Murphy, C., Rauter, M., Papathoma-Kohle, M., Servain, S., and Fuchs, S.: Drivers and barriers of adaptation initiatives - How societal transformation affects natural hazard management and risk mitigation in Europe, Sci. Total Environ., 650, 1073-1082, 985 https://doi.org/10.1016/j.scitotenv.2018.08.306, 2019.

Tufescu, V.: Inundațiile Bahluiului [Bahlui floodings], Revista Ştiinţifică VasileAdamachi, 21, 99-103 (in Romanian), 1935. UNDRR: Human cost of disasters. An overview of the last 20 years (2000-2019), available at: file://C:/Users/Office/AppData/Local/Temp/Human\%20Cost\%20of\%20Disasters\%202000-2019\%20Report\%20\%20UN\%20Office\%20for\%20Disaster\%20Risk\%20Reduction.pdf, last accessed: 19January 2021.

990 Van Well, L., van der Keur, P., Harjanne, A., Pagneux, E., Perrels, A., and Henriksen, H. J.: Resilience to natural hazards: An analysis of territorial governance in the Nordic countries, Int. J. Disast. Risk Re., 31, 1283-1294, https://doi.org/10.1016/j.ijdrr.2018.01.005, 2018.

van Westen, C. J., Hazarika, M. K., and Nashrrullah, S: ICT for Disaster Risk Management, Asian and Pacific Training Centre for Information and Communication Technology for Development (APCICT/ESCAP), Korea. 2020.

995 Vanneuville, W., Mzsiak, J., Füssel, H.-M., Kurnik, B., Kendrovski, V., Semenya, J.C., Suk, J.E., Olesen, J.E., Niemeyer, S., Ceglar, A., Roggero, P.P., Lehtonene, H., Schönhart, M., Kipling, R., Vogt, J., Spinoni, J., Perrels, A., Crawford-Brown, D., Kiviluoma, J., Aparicio, A., Georgi, B., Leitner, M., Bigano, A., Perrels, A., and Prettenthaler, F.: Climate change impacts on society, in: Climate change, impacts and vulnerability in Europe 2016. An indicator-based report. European Environment Agency Report1,189-266, http://doi.org/10.2800/534806, 2017.

1000 Velea, L. and Bojariu, R.: Summer thermal discomfort conditions in Romania under climate change, Carpathian J. Earth Env., 13, 595-603, http://dx.doi.org/10.26471/cjees/2018/013/050, 2018. 
van Vuuren, D.P., Edmonds, J., Kainuma, M., Riahi, K., Thomson, A., Hibbard, K., Hurtt, G.C., Kram, T., Krey, V., Lamarque, J.-F., Matsui, T., Meinshausen, M., Nakicenovic, N., Smith, S.J., and Rose, S.K.: Representative concentration pathways: an overview, Climatic Change, 109, 5-31, https://doi.org/10.1007/s10584-011-0148-z, 2011.

1005 Van der Linden, S.: On the relationship between personal experience, affect and risk perception: The case of climate change, Eur. J. Soc. Psychol., 44, 430-440, https://doi.org/10.1002/ejsp.2008, 2014.

Văculişteanu, G., Niculiţă, M. and Mărgărint, M.C.: Natural hazards and their impact on rural settlements in NE Romania - A cartographical approach. Open Geosciences, 11, 765-782, https://doi.org/10.1515/geo-2019-0060, 2019.

Vousdoukas, M.I., Mentaschi, L., Voukouvalas, E., Bianchi, A., Dottori, F., and Feyen, L.: Climatic and socioeconomic controls of future coastal flood risk in Europe, Nat. Clim. Change, 8, 776-780, https://doi.org/10.1038/s41558-018-0260-4, 2018.

Weber, E.U.: Experience-Based and Description-Based Perceptions of Long-Term Risk: Why Global Warming does not Scare us (Yet), Climatic Change, 77, 103-120, https://doi.org/10.1007/s10584-006-9060-3, 2006.

Wilson, G.A.: Assessing the environmental impact of the environmentally sensitive areas scheme: a case for using farmers'

1015 environmental knowledge? Landscape Res., 22, 303-326, https://doi.org/10.1080/01426399708706517, 1997.

World Health Organization: COVID-19 Strategy Update, 14 April 2020.

Worldometers: https:/www.worldometers.info/coronavirus/worldwide-graphs/\#total-deaths, last accessed: 24January 2021.

Zhao, D., McCoy, A.P., Kleiner, B.M., Mills, T.H., and Lingard, H.: Stakeholder perceptions of risk in construction, Safety Sci., 82, 111-119, http://dx.doi.org/10.1016/j.ssci.2015.09.002, 2016.

1020 Zhou, L., Wu, X., Xu, Z., and Fujita, H.: Emergency decision making for natural disasters: An overview, Int. J. Disast. Risk Re. 27, 567-576, https://doi.org/10.1016/j.ijdrr.2017.09.037, 2018.

Ziarul de Iaşi: https://www.ziaruldeiasi.ro/local/starea-de-alerta-se-mentine-in-zona-prutului $\sim$ ni4srt, 1 August 2008, last accessed: 24January 2021.

\section{Appendix A}

Table A1. Questionnaire sample and variables' units of measurement.

\begin{tabular}{|l|l|l|l|}
\hline Section & Question & Sub-sections items & Responses \\
\hline The level of threat & $\begin{array}{l}\text { Q1: On a scale from 1 to 5, how do you } \\
\text { think these factors could be a threat for the } \\
\text { quality of the life of your community? }\end{array}$ & $\begin{array}{l}\text { Level of development; Criminality; } \\
\text { Technological risks; Natural risks; } \\
\text { Environmental pollution; Climatic } \\
\text { changes }\end{array}$ & $\begin{array}{l}\text { 5-point } \\
\text { scale* }\end{array}$ \\
\cline { 2 - 5 } & $\begin{array}{l}\text { Q2: Considering a set of natural hazards, } \\
\text { how these events could be a threat/danger } \\
\text { for your community? }\end{array}$ & $\begin{array}{l}\text { Floods; Rainstorms; Snowstorms; Droughts; Soil } \\
\text { erosion }\end{array}$ & \begin{tabular}{l} 
5-point Likert scale \\
\hline
\end{tabular} \\
\hline
\end{tabular}




\begin{tabular}{|c|c|c|c|}
\hline & $\begin{array}{l}\text { Q3: Considering a set of natural hazards, } \\
\text { how these events could be a threat/danger } \\
\text { for your personally? }\end{array}$ & $\begin{array}{l}\text { Floods; Earthquakes; Landslides; } \\
\text { Rainstorms; Snowstorms; Droughts; Soil } \\
\text { erosion }\end{array}$ & 5-point Likert scale \\
\hline & $\begin{array}{l}\text { Q4: Considering a set of natural hazards, } \\
\text { what's the probability that these events } \\
\text { could happen in the place where you live } \\
\text { or nearby? }\end{array}$ & $\begin{array}{l}\text { Floods; Earthquakes; Landslides; } \\
\text { Rainstorms; Snowstorms; Droughts; Soil } \\
\text { erosion }\end{array}$ & 5-point Likert scale \\
\hline & $\begin{array}{l}\text { Q5: Do you think that these events could } \\
\text { be more a frequent threat/danger for the } \\
\text { next generations? }\end{array}$ & $\begin{array}{l}\text { Floods; Earthquakes; Landslides; } \\
\text { Rainstorms; Snowstorms; Droughts; Soil } \\
\text { erosion }\end{array}$ & dichotomic \\
\hline Past experiences & $\begin{array}{l}\text { Q6: Do you ever experienced these events } \\
\text { that have produced direct damage to you } \\
\text { personally? }\end{array}$ & $\begin{array}{l}\text { Floods; Earthquakes; Landslides; } \\
\text { Rainstorms; Snowstorms; Droughts; Soil } \\
\text { erosion }\end{array}$ & dichotomic \\
\hline \multirow[t]{4}{*}{$\begin{array}{l}\text { Knowledge about } \\
\text { hazards }\end{array}$} & $\begin{array}{l}\text { Q7: Which of the following have } \\
\text { contributed to your personal knowledge } \\
\text { about natural hazards? }\end{array}$ & $\begin{array}{l}\text { National awareness campaign; Social } \\
\text { networks on internet; Local administration } \\
\text { campaigns; TV/radio; Personal interest; } \\
\text { School; Participation to volunteerism } \\
\text { activities; } \\
\text { members/neighbours }\end{array}$ & dichotomic \\
\hline & $\begin{array}{l}\text { Q8: It would be interesting for you to be } \\
\text { more informed about natural hazards in } \\
\text { order to be more prepared in the case they } \\
\text { will happen here? }\end{array}$ & $\begin{array}{l}\text { Floods; Earthquakes; Landslides; } \\
\text { Rainstorms; Snowstorms; Droughts; Soil } \\
\text { erosion }\end{array}$ & 5-point Likert scale \\
\hline & $\begin{array}{l}\text { Q12: Which factors do you think might } \\
\text { exacerbate the negative consequences of } \\
\text { natural hazards? }\end{array}$ & $\begin{array}{l}\text { Climate change; deforestation; Lack of } \\
\text { protective structural device's; Lack of } \\
\text { protective structural device's } \\
\text { maintenance; Uncontrolled urbanization } \\
\text { and unmanaged land use planning; } \\
\text { Construction of buildings in areas at high } \\
\text { risk; Unsafe infrastructure buildings }\end{array}$ & 5-point Likert scale \\
\hline & $\begin{array}{l}\text { Q13: Which factors do you think might } \\
\text { reduce the negative consequences of } \\
\text { natural hazards and must be taken as a } \\
\text { priority in the place where you live? }\end{array}$ & $\begin{array}{l}\text { A proper legislation for land and urban } \\
\text { planning; A proper compensation scheme } \\
\text { for natural hazards victims; Build new } \\
\text { protection works; Ensure more } \\
\text { investments on controlling, monitoring } \\
\text { and maintaining actual protection works; } \\
\text { Increasing the level of awareness and }\end{array}$ & 5-point Likert scale \\
\hline
\end{tabular}




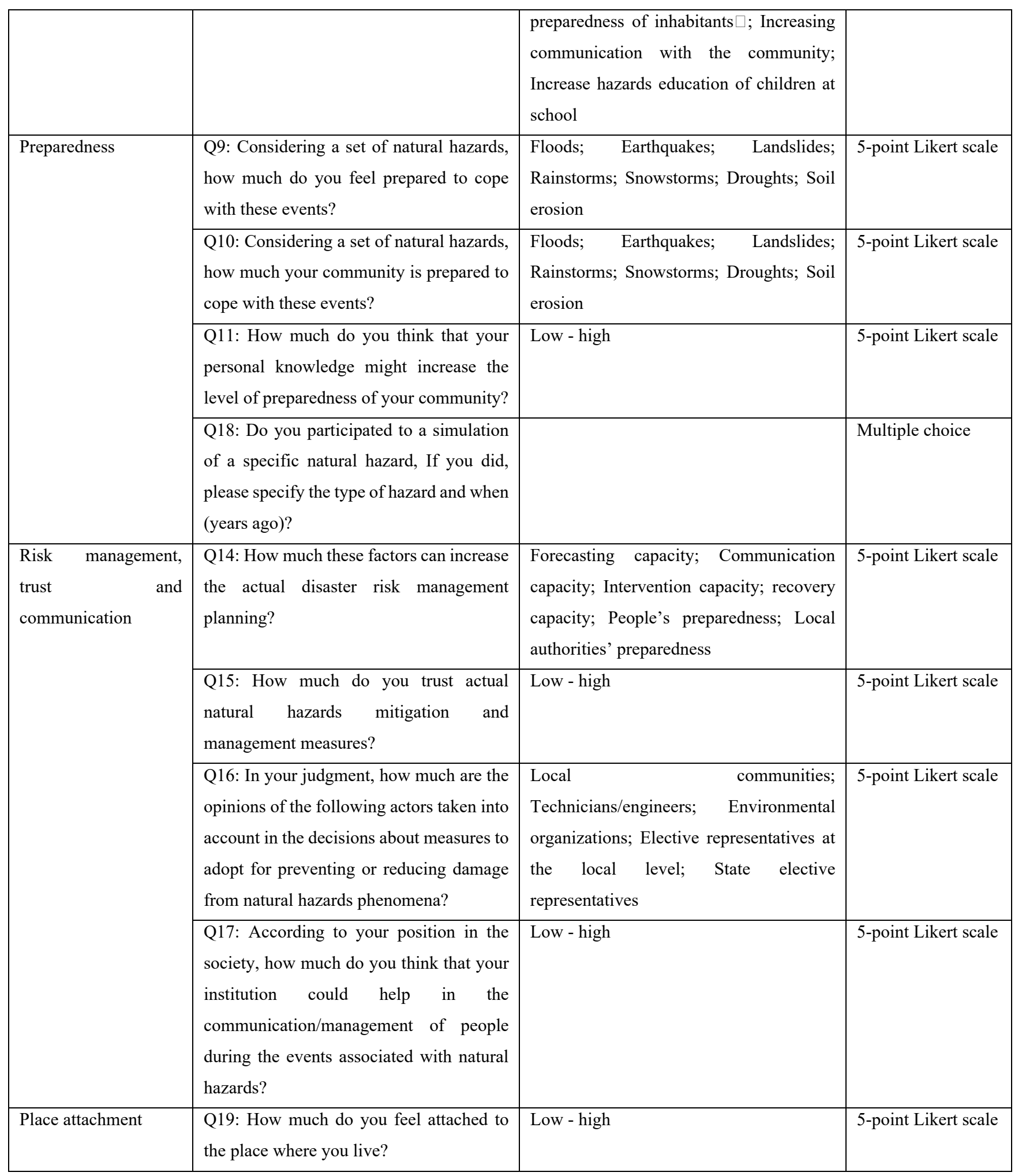




\begin{tabular}{|l|l|l|l|}
\hline \multirow{5}{*}{$\begin{array}{l}\text { Interviewee person } \\
\text { settings }\end{array}$} & PS1: Age & & Open \\
\cline { 2 - 5 } & PS2: Gender & & Dichotomic \\
\cline { 2 - 5 } & PS3: Education & Mayor; School Head; Policeman; Priest; & Multiple choice \\
\cline { 2 - 5 } & PS4: Profession & Darmer & Dichotomic \\
& $\begin{array}{l}\text { PS5: Do you live in the locality where you } \\
\text { are active? }\end{array}$ & $\begin{array}{l}\text { Your/your family property; Rented; } \\
\text { PS6: The house you are living in is: }\end{array}$ & Open \\
\cline { 2 - 5 } & $\begin{array}{l}\text { PS7: Including yourself, how many people } \\
\text { are there in your household? Number: }\end{array}$ & & Open \\
\hline
\end{tabular}

Table A2. The most frequent responses and the Asymptotic Generalized Pearson Chi-Square dependence test results for stakeholder types (with bold are the questions tested for independence).

\begin{tabular}{|c|c|c|c|c|c|c|c|c|}
\hline \multirow{2}{*}{$\begin{array}{c}\text { Question } \\
\text { ID }\end{array}$} & \multicolumn{8}{|c|}{ Sub-sections items } \\
\hline & $\mathrm{a}$ & $\mathrm{b}$ & $\mathrm{c}$ & $\mathrm{d}$ & $\mathrm{e}$ & $\mathrm{f}$ & $\mathrm{g}$ & $\mathrm{h}$ \\
\hline Q1* & 5 & 3 & 1 & 4 & 2 & 2 & - & - \\
\hline Q2* & 1 & 3 & 3 & 3 & 4 & 4 & 2 & - \\
\hline Q3* & 2 & 4 & 2 & 3 & 3 & 4 & 3 & - \\
\hline Q4* & 1 & 3 & 1 & 2 & 2 & 3 & 1 & - \\
\hline Q5* & $\mathrm{N}$ & $\mathrm{Y}$ & $\mathrm{N}$ & $\mathrm{Y}$ & $\mathrm{Y}$ & $\mathrm{Y}$ & $\mathrm{N}$ & - \\
\hline Q6* & $\mathrm{Y}$ & $\mathrm{Y}$ & $\mathrm{Y}$ & $\mathrm{Y}$ & $\mathrm{Y}$ & $\mathrm{N}$ & $\mathrm{Y}$ & - \\
\hline Q7* & $\mathrm{N}$ & $Y$ & $\mathrm{~N}$ & $\mathrm{Y}$ & $\mathrm{Y}$ & $\mathrm{N}$ & $\mathrm{N}$ & $\mathrm{Y}$ \\
\hline Q9* & 3 & 2 & 2 & 2 & 3 & 2 & 2 & - \\
\hline Q10* & 2 & 2 & 2 & 2 & 3 & 2 & 2 & - \\
\hline Q11* & 4 & - & - & - & - & - & - & - \\
\hline Q12* & 4 & 4 & 4 & 4 & 3 & 4 & 4 & - \\
\hline Q13* & 4 & 2 & 4 & 4 & 4 & 4 & 5 & - \\
\hline Q14* & 4 & 4 & 5 & 4 & 5 & 5 & - & - \\
\hline Q16* & 4 & 4 & 3 & 4 & 4 & - & - & - \\
\hline Q8 & 5 & & & & & & & \\
\hline Q15 & 3 & P8 & $\mathrm{N}$ & & & & & \\
\hline Q17 & 4 & P9 & 4 & & & & & \\
\hline 019 & 5 & P10 & 4 & & & & & \\
\hline
\end{tabular}




\begin{tabular}{|l|l|l|l|}
\hline P5 & Y & P11 & 4 \\
\hline P6 & 1 & P12 & 5 \\
\hline
\end{tabular}

*No independence at 0.0001 level, Y - Yes, No - No, 1 - Very Low, 2 - Low, 3 - Medium, 4 - High, 5 - Very High

Table A3. The Kruskal-Wallis rank-sum test (left part) and Freeman's epsilon-squared statistics (right part) for every category of risks and natural risks and stakeholder type, village, commune, flooded or non-flooded, age, gender, education

\begin{tabular}{|c|c|c|c|c|c|c|c|c|c|c|c|c|c|c|c|c|c|}
\hline & & 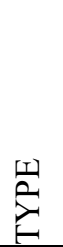 & 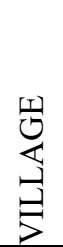 & $\sum_{0}^{\sum_{0}^{\prime}}$ & 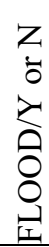 & 뉜 & 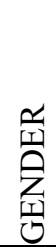 & 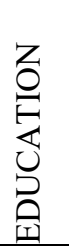 & & & $\stackrel{\underline{\nu}}{\vec{\nu}}$ & 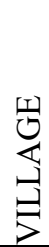 & 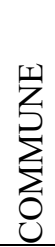 & $\begin{array}{l}z \\
\vdots \\
0 \\
z \\
0 \\
0 \\
0 \\
0 \\
1\end{array}$ & 讪 & 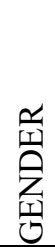 & 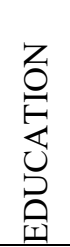 \\
\hline \multirow{6}{*}{ Q1 } & $\mathrm{a}$ & $\mathrm{D}$ & $\mathrm{D}$ & $\mathrm{D}$ & $\mathrm{D}$ & $\mathrm{D}$ & $\mathrm{D}$ & $\mathrm{D}$ & \multirow{6}{*}{ Q1 } & $\mathrm{a}$ & 0.8 & 0.1 & 0.2 & 1.0 & 1.0 & 1.0 & 0.6 \\
\hline & b & $\mathrm{D}$ & $\mathrm{D}$ & $\mathrm{D}$ & $\mathrm{D}$ & ND & 0 & ND & & $\mathrm{b}$ & 0.4 & 0.1 & 0.2 & 1.0 & 0.0 & - & 0.0 \\
\hline & $\mathrm{c}$ & $\mathrm{D}$ & $\mathrm{D}$ & $\mathrm{D}$ & 0 & $\mathrm{D}$ & $\mathrm{D}$ & $\mathrm{D}$ & & $\mathrm{c}$ & 0.1 & 0.2 & 0.1 & - & 0.8 & 1.0 & 0.9 \\
\hline & d & D & $\mathrm{D}$ & D & 0 & D & D & 0 & & $\mathrm{~d}$ & 0.9 & 0.1 & 0.1 & - & 0.8 & 1.0 & - \\
\hline & $\mathrm{e}$ & ND & $\mathrm{D}$ & $\mathrm{D}$ & $\mathrm{D}$ & 0 & $\mathrm{D}$ & $\mathrm{D}$ & & $\mathrm{e}$ & 0.2 & 0.0 & 0.2 & 1.0 & & 1.0 & 0.9 \\
\hline & $\mathrm{f}$ & $\mathrm{D}$ & $\mathrm{D}$ & $\mathrm{D}$ & D & $\mathrm{D}$ & $\mathrm{D}$ & $\mathrm{D}$ & & $\mathrm{f}$ & 0.5 & 0.1 & 0.2 & 1.0 & 1.0 & 1.0 & 0.9 \\
\hline \multirow{7}{*}{ Q2 } & $\mathrm{a}$ & ND & $\mathrm{D}$ & $\mathrm{D}$ & D & ND & $\mathrm{D}$ & ND & \multirow{7}{*}{ Q2 } & $\mathrm{a}$ & 0.0 & 0.0 & 0.3 & 1.0 & 0.0 & 1.0 & 0.1 \\
\hline & $\mathrm{b}$ & ND & $\mathrm{D}$ & $\mathrm{D}$ & 0 & $\mathrm{D}$ & 0 & $\mathrm{D}$ & & $\mathrm{b}$ & 0.0 & 0.1 & 0.2 & - & 0.8 & - & 0.2 \\
\hline & $\mathrm{c}$ & $\mathrm{D}$ & $\mathrm{D}$ & $\mathrm{D}$ & $\mathrm{D}$ & $\mathrm{D}$ & 0 & $\mathrm{D}$ & & $\mathrm{c}$ & 0.9 & 0.1 & 0.3 & 1.0 & 0.8 & - & 0.6 \\
\hline & $\mathrm{d}$ & $\mathrm{D}$ & ND & $\mathrm{D}$ & 0 & D & $\mathrm{D}$ & $\mathrm{D}$ & & $\mathrm{d}$ & 0.5 & 0.0 & 0.0 & - & 0.8 & 1.0 & 0.9 \\
\hline & $\mathrm{e}$ & $\mathrm{D}$ & $\mathrm{D}$ & $\mathrm{D}$ & $\mathrm{D}$ & $\mathrm{D}$ & $\mathrm{D}$ & $\mathrm{D}$ & & $\mathrm{e}$ & 0.5 & 0.1 & 0.3 & 1.0 & 1.0 & 1.0 & 0.6 \\
\hline & $\mathrm{f}$ & ND & $\mathrm{ND}$ & ND & 0 & $\mathrm{D}$ & $\mathrm{D}$ & $\mathrm{D}$ & & $\mathrm{f}$ & 0.0 & 0.0 & 0.0 & - & 0.8 & 1.0 & 0.2 \\
\hline & $\mathrm{g}$ & $\mathrm{D}$ & $\mathrm{D}$ & $\mathrm{D}$ & $\mathrm{D}$ & D & $\mathrm{D}$ & $\mathrm{D}$ & & $\mathrm{g}$ & 0.5 & 0.1 & 0.3 & 1.0 & 0.8 & 1.0 & 1.0 \\
\hline \multirow{7}{*}{ Q3 } & $\mathrm{a}$ & ND & $\mathrm{D}$ & $\mathrm{D}$ & $\mathrm{D}$ & 0 & $\mathrm{D}$ & $\bar{D}$ & \multirow{7}{*}{ Q3 } & $a$ & 0.0 & 0.1 & 0.1 & 1.0 & - & 1.0 & 0.2 \\
\hline & $b$ & ND & ND & ND & 0 & $\mathrm{D}$ & 0 & 0 & & $\mathrm{~b}$ & 0.1 & 0.0 & 0.0 & - & 0.8 & - & - \\
\hline & $\mathrm{c}$ & $\mathrm{D}$ & $\mathrm{D}$ & $\mathrm{D}$ & 0 & $\mathrm{D}$ & $\mathrm{D}$ & $\mathrm{D}$ & & $\mathrm{c}$ & 0.8 & 0.1 & 0.1 & - & 0.8 & 1.0 & 0.2 \\
\hline & $\mathrm{d}$ & $\mathrm{D}$ & $\mathrm{D}$ & $\mathrm{D}$ & 0 & $\mathrm{D}$ & 0 & 0 & & $\mathrm{~d}$ & 0.1 & 0.1 & 0.2 & - & 0.8 & - & - \\
\hline & $\mathrm{e}$ & $\mathrm{D}$ & $\mathrm{D}$ & $\mathrm{D}$ & 0 & 0 & $\mathrm{D}$ & $\mathrm{D}$ & & $\mathrm{e}$ & 0.5 & 0.1 & 0.1 & - & - & 1.0 & 0.6 \\
\hline & $\mathrm{f}$ & ND & $\mathrm{D}$ & $\mathrm{D}$ & 0 & $\mathrm{D}$ & $\mathrm{D}$ & ND & & $\mathrm{f}$ & 0.2 & 0.1 & 0.4 & - & 0.8 & 1.0 & 0.1 \\
\hline & $\mathrm{g}$ & ND & $\mathrm{D}$ & $\mathrm{D}$ & $\mathrm{D}$ & 0 & $\mathrm{D}$ & $\mathrm{D}$ & & $\mathrm{g}$ & 0.1 & 0.2 & 0.6 & 1.0 & - & 1.0 & 0.8 \\
\hline $\mathrm{Q} 4$ & a & 0 & $\mathrm{D}$ & $\mathrm{D}$ & $\mathrm{D}$ & $\mathrm{D}$ & 0 & ND & Q4 & $\mathrm{a}$ & - & 0.1 & 0.2 & 1.0 & 0.8 & - & 0.1 \\
\hline
\end{tabular}




\begin{tabular}{|c|c|c|c|c|c|c|c|c|c|c|c|c|c|c|c|c|c|}
\hline & $\mathrm{b}$ & $\mathrm{D}$ & $\mathrm{D}$ & $\mathrm{D}$ & $\mathrm{D}$ & $\mathrm{D}$ & $\mathrm{D}$ & ND & & $b$ & 0.5 & 0.1 & 0.2 & 1.0 & 0.8 & 1.0 & 0.1 \\
\hline & $\mathrm{c}$ & $\mathrm{D}$ & $\mathrm{D}$ & $\mathrm{D}$ & 0 & $\mathrm{D}$ & 0 & ND & & $\mathrm{c}$ & 0.1 & 0.1 & 0.1 & - & 0.8 & - & 0.0 \\
\hline & $\mathrm{d}$ & $\mathrm{D}$ & $\mathrm{D}$ & ND & 0 & 0 & $\mathrm{D}$ & $\mathrm{D}$ & & $\mathrm{d}$ & 0.8 & 0.2 & 0.0 & - & - & 1.0 & 0.6 \\
\hline & $\mathrm{e}$ & ND & $\mathrm{D}$ & $\mathrm{D}$ & 0 & $\mathrm{D}$ & 0 & D & & $\mathrm{e}$ & 0.1 & 0.1 & 0.2 & - & 0.8 & - & 0.6 \\
\hline & $\mathrm{f}$ & $\mathrm{D}$ & $\mathrm{D}$ & $\mathrm{D}$ & 0 & $\mathrm{D}$ & 0 & $\mathrm{D}$ & & $\mathrm{f}$ & 0.5 & 0.1 & 0.3 & - & 0.8 & - & 0.6 \\
\hline & $\mathrm{g}$ & $\mathrm{D}$ & $\mathrm{D}$ & $\mathrm{D}$ & 0 & 0 & 0 & $\mathrm{D}$ & & $\mathrm{g}$ & 0.5 & 0.1 & 0.0 & - & - & - & 0.9 \\
\hline \multirow{7}{*}{ Q5 } & $\mathrm{a}$ & ND & $\mathrm{D}$ & $\mathrm{D}$ & $\mathrm{D}$ & ND & $\mathrm{D}$ & ND & \multirow{7}{*}{ Q5 } & $\mathrm{a}$ & 0.1 & 0.0 & 0.1 & 1.0 & 0.0 & 1.0 & 0.1 \\
\hline & $\mathrm{b}$ & $\mathrm{ND}$ & $\mathrm{D}$ & $\mathrm{D}$ & $\mathrm{D}$ & ND & 0 & ND & & $\mathrm{b}$ & 0.1 & 0.0 & 0.1 & 1.0 & 0.0 & - & 0.1 \\
\hline & $\mathrm{c}$ & ND & $\mathrm{D}$ & $\mathrm{D}$ & $\mathrm{D}$ & 0 & $\mathrm{D}$ & $\mathrm{D}$ & & $\mathrm{c}$ & 0.0 & 0.1 & 0.2 & 1.0 & - & 1.0 & 0.6 \\
\hline & $\mathrm{d}$ & $\mathrm{D}$ & $\mathrm{D}$ & $\mathrm{D}$ & 0 & 0 & 0 & 0 & & $\mathrm{~d}$ & 0.1 & 0.1 & 0.2 & - & - & - & - \\
\hline & $\mathrm{e}$ & $\mathrm{D}$ & $\mathrm{D}$ & $\mathrm{D}$ & 0 & 0 & 0 & 0 & & $\mathrm{e}$ & 0.1 & 0.0 & 0.4 & - & - & - & - \\
\hline & $\mathrm{f}$ & 0 & 0 & 0 & 0 & 0 & 0 & 0 & & $\mathrm{f}$ & - & - & - & - & - & - & - \\
\hline & $\mathrm{g}$ & $\mathrm{D}$ & $\mathrm{D}$ & $\mathrm{D}$ & $\mathrm{D}$ & 0 & 0 & $\mathrm{D}$ & & $\mathrm{g}$ & 0.8 & 0.0 & 0.2 & 1.0 & - & - & 0.6 \\
\hline \multirow{7}{*}{ Q6 } & $\mathrm{a}$ & 0 & $\mathrm{D}$ & $\mathrm{D}$ & $\mathrm{D}$ & 0 & 0 & 0 & \multirow{7}{*}{ Q6 } & $\mathrm{a}$ & - & 0.1 & 0.1 & 1.0 & - & - & - \\
\hline & $\mathrm{b}$ & 0 & $\mathrm{D}$ & ND & 0 & 0 & 0 & 0 & & $\mathrm{~b}$ & - & 0.2 & 0.0 & - & - & - & - \\
\hline & $\mathrm{c}$ & 0 & ND & $\mathrm{D}$ & 0 & 0 & 0 & ND & & $\mathrm{c}$ & - & 0.0 & 0.1 & - & - & - & 0.1 \\
\hline & $\mathrm{d}$ & $\mathrm{D}$ & $\mathrm{D}$ & ND & 0 & 0 & 0 & $\mathrm{D}$ & & $\mathrm{d}$ & 0.5 & 0.0 & 0.0 & - & - & - & 0.2 \\
\hline & $\mathrm{e}$ & 0 & $\mathrm{D}$ & ND & 0 & 0 & 0 & 0 & & $\mathrm{e}$ & & 0.1 & 0.0 & & & & \\
\hline & $\mathrm{f}$ & $\mathrm{D}$ & $\mathrm{D}$ & $\mathrm{D}$ & 0 & 0 & 0 & 0 & & $\mathrm{f}$ & 0.3 & 0.1 & 0.1 & & & & \\
\hline & $\mathrm{g}$ & 0 & $\mathrm{D}$ & 0 & 0 & 0 & 0 & ND & & $\mathrm{g}$ & & 0.1 & & & & & 0.1 \\
\hline \multirow{8}{*}{ Q7 } & $\mathrm{a}$ & ND & ND & ND & $\mathrm{D}$ & ND & $\mathrm{D}$ & ND & \multirow{8}{*}{ Q7 } & $\mathrm{a}$ & 0.1 & 0.0 & 0.0 & 1.0 & 0.0 & 1.0 & 0.0 \\
\hline & $\mathrm{b}$ & ND & $\mathrm{D}$ & ND & $\mathrm{D}$ & ND & 0 & ND & & $\mathrm{b}$ & 0.0 & 0.0 & 0.0 & 1.0 & 0.0 & & 0.0 \\
\hline & $\mathrm{c}$ & $\mathrm{D}$ & ND & $\mathrm{D}$ & $\mathrm{D}$ & 0 & 0 & 0 & & $\mathrm{c}$ & 0.1 & 0.0 & 0.0 & 1.0 & - & - & - \\
\hline & $\mathrm{d}$ & 0 & ND & ND & 0 & 0 & 0 & 0 & & $\mathrm{~d}$ & - & 0.0 & 0.0 & - & - & - & - \\
\hline & $\mathrm{e}$ & 0 & $\mathrm{D}$ & $\mathrm{D}$ & 0 & 0 & 0 & 0 & & $\mathrm{e}$ & - & 0.1 & 0.0 & - & - & - & - \\
\hline & $\mathrm{f}$ & $\mathrm{D}$ & ND & $\mathrm{D}$ & 0 & 0 & 0 & 0 & & $\mathrm{f}$ & 0.3 & 0.0 & 0.1 & - & - & - & - \\
\hline & $\mathrm{g}$ & 0 & ND & $\mathrm{D}$ & $\mathrm{D}$ & 0 & $\mathrm{D}$ & 0 & & $\mathrm{~g}$ & - & 0.0 & 0.0 & 1.0 & - & 1.0 & - \\
\hline & $\mathrm{h}$ & $\mathrm{D}$ & $\mathrm{D}$ & $\mathrm{ND}$ & 0 & 0 & 0 & ND & & $\mathrm{h}$ & 0.1 & 0.0 & 0.0 & - & - & - & 0.1 \\
\hline \multicolumn{2}{|l|}{ Q8 } & ND & $\mathrm{D}$ & ND & 0 & $\mathrm{D}$ & $\mathrm{D}$ & $\mathrm{D}$ & \multicolumn{2}{|l|}{ Q8 } & 0.2 & 0.1 & 0.0 & - & 0.8 & 1.0 & $\overline{0.9}$ \\
\hline \multirow{3}{*}{ Q9 } & $\mathrm{a}$ & $\mathrm{D}$ & $\mathrm{D}$ & ND & $\mathrm{D}$ & $\mathrm{D}$ & $\mathrm{D}$ & $\mathrm{D}$ & \multirow{3}{*}{ Q9 } & $\mathrm{a}$ & 0.8 & 0.1 & 0.0 & 1.0 & 0.8 & 1.0 & 0.6 \\
\hline & $\mathrm{b}$ & $\mathrm{D}$ & $\mathrm{D}$ & $\mathrm{D}$ & 0 & $\mathrm{D}$ & 0 & $\mathrm{D}$ & & $\mathrm{b}$ & 0.5 & 0.3 & 0.4 & - & 0.8 & - & 0.9 \\
\hline & $\mathrm{c}$ & ND & $\mathrm{D}$ & $\mathrm{D}$ & $\mathrm{D}$ & $\mathrm{D}$ & $\mathrm{D}$ & $\mathrm{D}$ & & $\mathrm{c}$ & 0.1 & 0.1 & 0.1 & 1.0 & 1.0 & 1.0 & 0.2 \\
\hline
\end{tabular}




\begin{tabular}{|c|c|c|c|c|c|c|c|c|c|c|c|c|c|c|c|c|c|}
\hline & $\mathrm{d}$ & ND & $\mathrm{D}$ & $\mathrm{D}$ & $\mathrm{D}$ & ND & $\mathrm{D}$ & ND & & $\mathrm{d}$ & 0.1 & 0.1 & 0.3 & 1.0 & 0.0 & 1.0 & 0.1 \\
\hline & $\mathrm{e}$ & $\mathrm{D}$ & $\mathrm{D}$ & $\mathrm{D}$ & 0 & $\mathrm{D}$ & 0 & 0 & & $\mathrm{e}$ & 0.9 & 0.1 & 0.3 & - & 0.8 & - & - \\
\hline & $\mathrm{f}$ & ND & $\mathrm{D}$ & $\mathrm{D}$ & 0 & $\mathrm{D}$ & 0 & $\mathrm{D}$ & & $\mathrm{f}$ & 0.0 & 0.1 & 0.3 & - & 0.8 & - & 0.6 \\
\hline & $\mathrm{g}$ & ND & $\mathrm{D}$ & $\mathrm{D}$ & 0 & 0 & 0 & ND & & $\mathrm{g}$ & 0.0 & 0.1 & 0.3 & - & - & - & 0.1 \\
\hline \multirow{7}{*}{ Q10 } & $\mathrm{a}$ & $\mathrm{D}$ & $\mathrm{D}$ & $\mathrm{D}$ & $\mathrm{D}$ & $\mathrm{D}$ & 0 & ND & \multirow{7}{*}{ Q10 } & $\mathrm{a}$ & 0.1 & 0.1 & 0.1 & 1.0 & 0.8 & - & 0.1 \\
\hline & $\mathrm{b}$ & $\mathrm{D}$ & ND & ND & 0 & $\mathrm{D}$ & 0 & $\mathrm{D}$ & & $\mathrm{b}$ & 0.5 & 0.0 & 0.0 & - & 1.0 & - & 0.6 \\
\hline & $\mathrm{c}$ & 0 & ND & $\mathrm{D}$ & 0 & 0 & $\mathrm{D}$ & ND & & $\mathrm{c}$ & - & 0.0 & 0.2 & - & - & 1.0 & 0.0 \\
\hline & $\mathrm{d}$ & $\mathrm{D}$ & ND & $\mathrm{D}$ & 0 & 0 & 0 & $\mathrm{D}$ & & $\mathrm{d}$ & 0.1 & 0.0 & 0.1 & - & - & - & 0.6 \\
\hline & $\mathrm{e}$ & ND & $\mathrm{D}$ & $\mathrm{D}$ & 0 & 0 & 0 & ND & & $\mathrm{e}$ & 0.0 & 0.0 & 0.1 & - & - & - & 0.1 \\
\hline & $\mathrm{f}$ & ND & $\mathrm{D}$ & $\mathrm{D}$ & 0 & $\mathrm{D}$ & 0 & ND & & $f$ & 0.1 & 0.0 & 0.1 & - & 0.8 & - & 0.1 \\
\hline & $\mathrm{g}$ & 0 & $\mathrm{D}$ & $\mathrm{D}$ & 0 & $\mathrm{D}$ & 0 & ND & & $\mathrm{g}$ & & 0.0 & 0.1 & - & 0.8 & - & 0.1 \\
\hline \multicolumn{2}{|l|}{ Q11 } & ND & $\mathrm{D}$ & $\mathrm{D}$ & 0 & $\mathrm{D}$ & $\mathrm{D}$ & $\mathrm{D}$ & \multicolumn{2}{|l|}{ Q11 } & 0.1 & 0.0 & 0.1 & - & 0.8 & 1.0 & 0.9 \\
\hline \multirow{7}{*}{ Q12 } & $\begin{array}{l}\mathrm{N} \\
\mathrm{I}\end{array}$ & $\mathrm{D}$ & $\mathrm{D}$ & $\mathrm{D}$ & 0 & $\mathrm{D}$ & 0 & $\mathrm{D}$ & \multirow{7}{*}{ Q12 } & $\mathrm{a}$ & 0.5 & 0.1 & 0.1 & - & 0.8 & - & 0.6 \\
\hline & $\mathrm{b}$ & $\mathrm{D}$ & $\mathrm{D}$ & $\mathrm{D}$ & 0 & 0 & 0 & ND & & $\mathrm{b}$ & 0.5 & 0.1 & 0.3 & - & - & - & 0.1 \\
\hline & $\mathrm{c}$ & 0 & $\mathrm{D}$ & $\mathrm{D}$ & 0 & 0 & 0 & 0 & & $\mathrm{c}$ & & 0.1 & 0.1 & - & - & - & - \\
\hline & $\mathrm{d}$ & $\mathrm{D}$ & $\mathrm{D}$ & $\mathrm{D}$ & 0 & $\mathrm{D}$ & 0 & 0 & & $\mathrm{~d}$ & 0.1 & 0.1 & 0.1 & - & 0.8 & - & - \\
\hline & $\mathrm{e}$ & $\mathrm{D}$ & $\mathrm{D}$ & $\mathrm{D}$ & 0 & $\mathrm{D}$ & $\mathrm{D}$ & $\mathrm{D}$ & & $\mathrm{e}$ & 0.8 & 0.0 & 0.1 & - & 0.8 & 1.0 & 0.6 \\
\hline & $\mathrm{f}$ & $\mathrm{D}$ & $\mathrm{D}$ & $\mathrm{D}$ & $\mathrm{D}$ & $\mathrm{D}$ & $\mathrm{D}$ & ND & & $\mathrm{f}$ & 0.5 & 0.0 & 0.1 & 1.0 & 0.8 & 1.0 & 0.1 \\
\hline & $\mathrm{g}$ & ND & ND & $\mathrm{D}$ & 0 & ND & $\mathrm{D}$ & $\mathrm{D}$ & & $\mathrm{g}$ & 0.0 & 0.1 & 0.0 & - & 0 & 1.0 & 0.6 \\
\hline \multirow{7}{*}{ Q13 } & $\mathrm{a}$ & $\mathrm{ND}$ & $\mathrm{D}$ & $\mathrm{D}$ & $\mathrm{D}$ & $\mathrm{D}$ & 0 & $\mathrm{D}$ & \multirow{7}{*}{ Q13 } & $\mathrm{a}$ & 0.1 & 0.1 & 0.1 & 1.0 & 1.0 & & 0.6 \\
\hline & $\mathrm{b}$ & $\mathrm{D}$ & $\mathrm{D}$ & $\mathrm{D}$ & $\mathrm{D}$ & $\mathrm{D}$ & $\mathrm{D}$ & ND & & $\mathrm{b}$ & 0.9 & 0.1 & 0.2 & 1.0 & 0.8 & 1.0 & 0.0 \\
\hline & $\mathrm{c}$ & $\mathrm{D}$ & $\mathrm{D}$ & $\mathrm{ND}$ & $\mathrm{D}$ & 0 & $\mathrm{D}$ & ND & & $\mathrm{c}$ & 0.1 & 0.1 & 0.0 & 1.0 & - & 1.0 & 0.0 \\
\hline & $\mathrm{d}$ & ND & ND & $\mathrm{D}$ & 0 & ND & $\mathrm{D}$ & ND & & $\mathrm{d}$ & 0.1 & 0.0 & 0.2 & - & 0.0 & 1.0 & 0.0 \\
\hline & $\mathrm{e}$ & $\mathrm{D}$ & $\mathrm{D}$ & $\mathrm{D}$ & 0 & $\mathrm{D}$ & $\mathrm{D}$ & $\mathrm{D}$ & & $\mathrm{e}$ & 0.8 & 0.0 & 0.2 & - & 0.8 & 1.0 & 0.6 \\
\hline & $\mathrm{f}$ & $\mathrm{D}$ & $\mathrm{D}$ & $\mathrm{D}$ & 0 & $\mathrm{D}$ & 0 & $\mathrm{ND}$ & & $f$ & 0.1 & 0.0 & 0.1 & - & 0.8 & - & 0.0 \\
\hline & $\mathrm{g}$ & $\mathrm{D}$ & ND & ND & 0 & $\mathrm{D}$ & 0 & ND & & $\mathrm{g}$ & 0.1 & 0.0 & 0.0 & - & 0.8 & - & 0.0 \\
\hline \multirow{5}{*}{ Q14 } & $\mathrm{a}$ & $\mathrm{D}$ & $\mathrm{D}$ & $\mathrm{D}$ & 0 & $\mathrm{D}$ & $\mathrm{D}$ & ND & \multirow{5}{*}{ Q14 } & $\mathrm{a}$ & 0.8 & 0.1 & 0.1 & - & 0.75 & 1.0 & 0.1 \\
\hline & $\mathrm{b}$ & $\mathrm{D}$ & $\mathrm{D}$ & $\mathrm{D}$ & 0 & $\mathrm{D}$ & $\mathrm{D}$ & $\mathrm{D}$ & & $\mathrm{b}$ & 0.9 & 0.0 & 0.5 & - & 0.75 & 1.0 & 0.6 \\
\hline & $\mathrm{c}$ & ND & $\mathrm{D}$ & ND & $\mathrm{D}$ & $\mathrm{D}$ & $\mathrm{D}$ & ND & & $\mathrm{c}$ & 0.1 & 0.1 & 0.0 & 1.0 & 0.75 & 1.0 & 0.0 \\
\hline & $\mathrm{d}$ & 0 & $\mathrm{D}$ & $\mathrm{D}$ & 0 & $\mathrm{D}$ & 0 & 0 & & $\mathrm{~d}$ & & 0.1 & 0.1 & - & 0.75 & - & - \\
\hline & $\mathrm{e}$ & ND & $\mathrm{D}$ & $\mathrm{ND}$ & 0 & $\mathrm{D}$ & $\mathrm{D}$ & $\mathrm{D}$ & & $\mathrm{e}$ & 0.1 & 0.1 & 0.0 & - & 0.75 & 1.0 & 0.6 \\
\hline
\end{tabular}




\begin{tabular}{|c|c|c|c|c|c|c|c|c|}
\hline & $\mathrm{f}$ & D & D & $\mathrm{D}$ & D & D & 0 & D \\
\hline \multicolumn{2}{|l|}{ Q15 } & D & $\mathrm{D}$ & $\mathrm{D}$ & 0 & D & $\mathrm{D}$ & $\mathrm{D}$ \\
\hline \multirow{5}{*}{ Q16 } & $\mathrm{a}$ & $\mathrm{D}$ & D & ND & 0 & 0 & 0 & 0 \\
\hline & $\mathrm{b}$ & $D$ & $\mathrm{D}$ & $\mathrm{D}$ & D & $\mathrm{D}$ & $\mathrm{D}$ & $\mathrm{ND}$ \\
\hline & $\mathrm{c}$ & D & $\mathrm{D}$ & D & 0 & D & $\mathrm{D}$ & ND \\
\hline & $\mathrm{d}$ & D & $\mathrm{D}$ & $\mathrm{D}$ & 0 & D & D & ND \\
\hline & $\mathrm{e}$ & D & $\mathrm{D}$ & $\mathrm{D}$ & D & D & $\mathrm{D}$ & $\mathrm{D}$ \\
\hline \multicolumn{2}{|l|}{ Q17 } & 0 & $\mathrm{D}$ & ND & 0 & 0 & 0 & ND \\
\hline \multicolumn{2}{|l|}{ Q19 } & D & $\mathrm{D}$ & ND & 0 & 0 & 0 & 0 \\
\hline \multicolumn{2}{|l|}{ P9 } & $\mathrm{D}$ & $\mathrm{D}$ & $\mathrm{D}$ & 0 & D & 0 & D \\
\hline
\end{tabular}

\begin{tabular}{|c|c|c|c|c|c|c|c|c|}
\hline & $\mathrm{f}$ & 0.1 & 0.0 & 0.2 & 1.0 & 0.75 & & 0.6 \\
\hline \multicolumn{2}{|l|}{ Q15 } & 0.8 & 0.0 & 0.0 & - & 1.0 & 1.0 & 0.6 \\
\hline \multirow{5}{*}{ Q16 } & $\mathrm{a}$ & 0.8 & 0.0 & 0.0 & - & - & - & - \\
\hline & b & 0.8 & 0.0 & 0.0 & 1.0 & 1.0 & 1.0 & 0.1 \\
\hline & $\mathrm{c}$ & 0.8 & 0.1 & 0.2 & - & 0.8 & 1.0 & 0.1 \\
\hline & d & 0.5 & 0.0 & 0.1 & - & 0.8 & 1.0 & 0.1 \\
\hline & $\mathrm{e}$ & 0.6 & 0.0 & 0.1 & 1.0 & 0.8 & 1.0 & 0.8 \\
\hline \multicolumn{2}{|l|}{ Q17 } & - & 0.0 & 0.0 & - & - & - & 0.1 \\
\hline \multicolumn{2}{|l|}{ Q19 } & 0.3 & 0.0 & 0.0 & - & - & - & - \\
\hline \multicolumn{2}{|l|}{ P9 } & 0.5 & 0.1 & 0.2 & - & 0.8 & - & 0.6 \\
\hline
\end{tabular}

$\mathrm{D}$ - there is a difference between different groups responses, ND - there is no difference between different groups responses; bold values bigger than 0.5 